\title{
The Sanskrit (Pseudo)Periphrastic Future
}

\begin{abstract}
The paradigmatic status of the Sanskrit periphrastic future is widely taken for granted. I argue that all the criteria for distinguishing the periphrastic future as a paradigmatic tense formation from a syntactic collocation of agent noun plus copula are problematic, except in one small set of Sanskrit texts. The evidence requires a nuanced diachronic approach: in early Vedic Prose we may reasonably speak of a paradigmatic 'periphrastic future' (though it may not be periphrastic), but outside this period the formation is merely a special use of the agent noun.
\end{abstract}

\section{INTRODUCTION}

According to traditional Sanskrit grammar, including standard Western accounts, the Sanskrit verbal paradigm includes a finite tense formation known as the 'periphrastic future'. ${ }^{1}$ This formation is of interest from both diachronic and synchronic perspectives. According to conventional wisdom, it is not found in the earliest attested stage of the language, Rgvedic Sanskrit, but develops by the early Vedic Prose period (perhaps one to three hundred years later) from a collocation involving an agent noun and a copula. In synchronic terms, points of research include its semantic distinction from the other Sanskrit finite future tense, the 'synthetic future' in -sya-, and the formal make-up of the periphrastic future paradigm, since it is not a morphologically straightforward periphrasis. A simple example of the periphrastic future is given in (1). ${ }^{2}$

$\begin{array}{llllll}\text { (1) } & \text { kartā } & \text { bhavān } & \text { karma } & \text { na samśayo 'sti } \\ \text { do.FUT.3SG } & \text { you.HON.NOM.SG } & \text { deed.ACC.SG } & \text { not } & \text { doubt.NOM.SG } & \text { is }\end{array}$

'You will do the deed, there is no doubt.' (MBh. 3.180.37)

The development and functionality of the Sanskrit periphrastic future have been investigated e.g. by Delbrück (1888: 289-296), Renou (1938), Gonda (1957), Campanile (1969), Hara (1987), and Tichy (1992), besides studies on the nouns in -tr- and -tŕ-, from which the periphrastic future developed, e.g. by Benveniste (1948), Tichy (1995), and Kiparsky (2016). A recent morphological analysis of the periphrastic future has been undertaken by Stump (2012). In this paper, I discuss the paradigmatic status of the periphrastic future. The crucial question is whether, or to what extent, the periphrastic future construction can be distinguished from a syntactic collocation of agent noun plus copula. If it cannot, then the periphrastic future does not exist as a distinct part of the Sanskrit verbal paradigm. A close relationship is widely recognized between the periphrastic future and the agent noun in -trwhich gave rise to it, but I argue that the close relation and interaction between the two formations has been severely underestimated. Crucially, all the criteria for distinguishing the periphrastic future as

\footnotetext{
${ }^{1}$ I am very grateful to Elizabeth Tucker, John Brockington, and three anonymous reviewers, for insightful comments on an earlier version of this paper. All remaining errors are my own. I was able to undertake this work due to a generous grant from the Jill Hart Fund for Indo-Iranian Philology at the University of Oxford.

${ }^{2}$ The pronoun bhavant-, nom.sg.masc. bhavān, is an honorific 2 sg. pronoun which shows 3 sg. agreement.
} 
distinct tense formation from a sequence of agent noun plus copula are problematic, except in a small set of Sanskrit texts. I argue that a nuanced diachronic approach to the status of the periphrastic future is required: in early Vedic Prose, there is evidence for an incipient 'periphrastic future' formation, although it remains somewhat in flux. Excepting this period, which attests a number of other linguistic peculiarities not continued in later Sanskrit, the formation is not a true periphrasis (in the sense to be defined below), but merely a special use of the agent noun. This special use is not without parallel even in the Rgveda, which is not thought to attest the periphrastic future.

This reassessment of the periphrastic future has a number of important consequences, including regarding the diachronic dialectology of Sanskrit, the date of Pānini, the definition of periphrasis, and the contrast between traditional grammatical assumptions and the evidence of texts.

\section{Periphrasis}

As a descriptive label for the construction in question, the term periphrastic future is by no means inappropriate. The question is whether, or to what degree, this descriptive label correlates with a modern linguistic understanding of periphrasis. Before tackling the Sanskrit data, therefore, it is necessary to establish an adequate definition of periphrasis. I adopt a paradigmatic, fundamentally morphological, approach to periphrasis, building on a wealth of research on the topic in recent years, e.g. by Börjars et al. (1997), Börjars \& Donohue (2000), Sadler \& Spencer (2002), Stump (2001, 2002), Spencer (2003, 2006, 2012), Ackerman \& Stump (2004), Bonami \& Samvelian (2009, 2015), Ackerman et al. (2011), Stump \& Hippisley (2011), Bonami \& Webelhuth (2012), Popova \& Spencer (2012) and Spencer \& Popova (2015).

In certain ways, a morphological approach to periphrasis runs counter to the traditional assumption that periphrasis is fundamentally a syntactic phenomenon. ${ }^{3}$ Descriptively, periphrasis does involve syntax: a periphrastic formation typically involves two distinct words, which appear in a syntactic relation in a sentence. The question is in what way, or whether, periphrasis is different from an ordinary syntactic relation between two words. From a paradigmatic perspective, the difference is morphological: a periphrastic formation typically involves two words, but together these two words fill one slot in the inflectional paradigm of a lexeme. For example, Kiparsky (2005) provides the following paradigm illustrating the tense and voice distinctions in the Latin verb system: ${ }^{4}$

\begin{tabular}{|c|c|c|}
\hline Non-perfect & Active & Passive \\
\hline Present & laudat 'praises' & laudātur 'is praised' \\
\hline Past & laudābat & laudābātur \\
\hline Future & laudābit & laudābitur \\
\hline \multicolumn{3}{|l|}{ Perfect } \\
\hline Present & laudāvit & laudāt-us/-ā/-um est \\
\hline Past & laudāverat & laudāt-us/-ä/-um erat \\
\hline Future & laudāverit & laudāt-us/-āal-um erit \\
\hline
\end{tabular}

Under this analysis, Latin distinguishes three tenses (present, past, future), two aspects (perfect, non-perfect), and two voices (active, passive). All twelve theoretically possible tense/aspect/voice combinations are expressed; nine of these are expressed using synthetic verb forms, but the perfect

\footnotetext{
${ }^{3}$ For a recent argument in this direction, see Kiparsky (2005).

${ }^{4}$ Kiparsky's 'Non-perfect past' is traditionally labelled the imperfect, his 'Perfect present' the perfect, and his 'Perfect past' the pluperfect.
} 
passive tenses are expressed using two word sequences of past participle plus copula. On a paradigmatic approach, a true periphrasis necessarily fills a slot in a paradigm in just this way.

Ackerman \& Stump (2004) propose three sufficient, but not necessary, criteria for identifying periphrasis: I. featurally intersective distribution; II. morphosyntactic non-compositionality; III. distributed exponence. These three criteria have been hugely influential, although none is without its difficulties.

Featurally intersective distribution is essentially what we have seen in (2): intersecting feature systems imply a paradigm consisting of a number of logically possible slots, and if a particular cell is not filled by a single word form, it may either be left unfilled (a defective paradigm), or else the cell may be filled by a periphrastic expression, i.e. an expression involving two (or more) words which stand in a syntactic relation to one another when employed in a sentence. This is argued to be the prime criterion for identifying periphrasis by Spencer \& Popova (2015). Spencer \& Popova (2015) adopt a strict view of the term periphrasis, seeking to define it in terms of a paradigmatic approach to inflection. They acknowledge that there are many types of construction which are in one way or another on the borderline between syntax and morphology, and there may be constructions which are more, or less, periphrastic than others. The most canonical periphrasis, however, necessarily involves featurally intersective distribution. Spencer \& Popova (2015) label this "intersective periphrasis". 5

As a sufficient criterion for periphrasis, featurally intersective distribution is relatively unproblematic. As a necessary criterion, however, it would rule out certain constructions which are typically labelled 'periphrastic'. For example, according to Spencer \& Popova (2015), the English progressive and perfect aspect verb categories, e.g. is X-ing, has X-ed, would not qualify as periphrastic expressions, because in English aspectual contrasts are never marked by synthetic morphology, meaning that there is no clear evidence for aspect as part of the English verbal paradigm.

Bonami \& Samvelian (2015), who broadly accept the criteria of Ackerman \& Stump (2004), propose an additional criterion, 'obligatoriness': "If the construction is necessary for some morphosyntactic feature value to be expressed, then the construction is periphrastic." Bonami \& Samvelian propose this criterion with reference to the Persian progressive construction: in Persian, progressive aspect can be expressed either by a progressive construction involving two word forms (a form of the verb 'have' with a finite lexical verb complement), or by a synthetic imperfective verb form. Bonami \& Samvelian (2015) argue that the lack of obligatoriness means that the progressive construction is not necessarily periphrastic. In other words, the progressive construction involving 'have' is not the way of expressing progressive aspect in Persian, so it is not a periphrasis: it is a syntactic construction which happens to express an aspectual value. This criterion extends Ackerman \& Stump's (2004) criterion I beyond the bounds of a paradigmatic feature system: the morphosyntactic feature value need not necessarily be a part of the intersecting feature system of a language. This might allow us to admit the English progressive and perfect aspect as periphrastic expressions, since these aspect values cannot be expressed synthetically. A problem with such an extension, however, is that it potentially expands the range of the term periphrasis to the point where it loses meaning. For example, we might then allow the term to apply to any multiword construction which expresses a grammatical feature, even if no values of that feature are expressed synthetically/morphologically. Haspelmath (2000: 655-656) terms this 'categorial' periphrasis, but notes that this would mean any construction containing function words would be classed as periphrastic, even in languages without morphology. For example, English noun phrases with definite articles, the dog, a cat, etc., would be periphrastic constructions, since the articles express a purely grammatical feature which cannot be expressed synthetically.

The second criterion proposed by Ackerman \& Stump (2004) is morphosyntactic non-compositionality:

\footnotetext{
${ }^{5}$ This corresponds to Haspelmath's (2000) "suppletive type (a)".
} 
if the construction as a whole expresses some feature which is not specified by the individual parts, then the construction is a periphrasis. Brown et al. (2012: 253) note that non-compositionality here can refer to two distinct phenomena, 'idiomaticity' and 'feature-clash'; in the former case, the construction expresses a property which is not a property of any element, while in the latter case the two elements of the construction clash in regard to a feature. In both cases, however, the criterion is problematic. As discussed by Spencer \& Popova (2015), the criterion depends on a prior definition of morphosyntactic features and their combinations. For example, we will see below that it is at least theoretically the case that certain person/number combinations of the Sanskrit periphrastic future involve a singular form of the agent noun combined with a plural form of the copula. Assuming that singular and plural are incompatible features ( $\mathrm{NUM}=\mathrm{SG}$ vs. $\mathrm{NUM}=\mathrm{PL}$ ), we are dealing with a feature clash. However, if singular number is treated as an unspecified, default value, then a combination of singular and plural does not clash, but would unproblematically resolve to plural ( $\mathrm{NUM}=\mathrm{PL}+\emptyset \Rightarrow \mathrm{NUM}=\mathrm{PL}$ ). Kiparsky (2005) argues against non-compositionality as a criterion for periphrasis on the grounds that idiomatic expressions are necessarily non-compositional, yet are syntactic. Brown et al. (2012) argue that noncompositionality may be a feature of periphrasis, but in their view canonical periphrasis is in fact compositional, in the sense of expressing a transparent relationship between meaning and form.

Bonami \& Samvelian (2015) accept non-compositionality as a criterion for periphrasis, but propose a slightly more nuanced definition:

\section{Mismatch between morphological exponence and phrasal features}

If the features of a phrasal combination do not match the features that are expected given the exponents carried by the pieces of the construction and independently established general principles of feature transmission, then the combination is periphrastic. (Bonami \& Samvelian 2015: 375)

Bonami \& Samvelian's point is that the relation between the elements of a periphrastic construction is not symmetrical: one element is the head (whether understood syntactically or morphologically), the other a non-head. Under general principles of feature transmission, features of a non-head are not necessarily expected to be features of a construction. For example, the Persian passive construction involves a perfect participle, but does not express perfect tense, yet this is not problematic since the participle is not the head of the construction.

The third criterion proposed by Ackerman \& Stump (2004) is distributed exponence. This criterion is the least intuitive of the three and, Spencer \& Popova (2015) argue, the least successful. By distributed exponence Ackerman \& Stump mean constructions in which features that might ordinarily be expressed together on a single word form (e.g. person and number on a verb) are expressed on different words in the putatively periphrastic construction. However, Spencer \& Popova (2015) show that in the Macedonian 'have'-perfect lack of distributed exponence is in fact evidence for the periphrastic status of the construction. A preferable way of viewing this criterion is as referring to constructions in which the distribution of morphosyntactic properties goes against the ordinary morphosyntax of the language (Spencer 2008, 2012). Whatever the best way of approaching this criterion from a typological perspective, it will not be relevant for the discussion of the Sanskrit periphrastic future, so I do not discuss it further.

Two additional criteria for periphrasis are proposed by Spencer (2006: 291): 'underexhaustivity' and 'overexhaustivity'. The former term applies where a function word in a periphrastic expression has fewer inflected forms than expected, the rationale being that arbitrary feature restrictions are more typical of morphology than syntax. For example, as discussed below the copula in the Sanskrit periphrastic future is largely restricted to indicative present forms, and past tense forms of the copula cannot be 
used. The term 'overexhaustivity' applies where a periphrastic expression gives rise to more combinations than might be expected given the ordinary rules of syntax in a language. This phenomenon is not found with the Sanskrit periphrastic future, so will not be discussed further.

A somewhat different approach to defining periphrasis is taken by Brown et al. (2012). Their aim is not to provide necessary or sufficient criteria for periphrasis, but to define 'canonical' periphrasis. This means that even if the criteria they propose are not met, a construction might still be analysable as periphrasis, though not a canonical one. As such, their criteria are of somewhat limited value for the question of whether something is or is not a periphrasis. Brown et al. (2012) argue that non-compositionality and distributed exponence are sometimes diagnostic of periphrasis, but are not canonical properties of it. They propose the following criteria:

(3) i. a periphrastic construction is a canonical functional syntactic construction;

ii. a periphrastic construction realizes a (canonical) grammatical feature;

iii. a periphrastic construction (like canonical syntax and canonical morphology) will exhibit a transparent relation between form and meaning;

iv. a periphrastic construction will occupy a cell in an otherwise inflected paradigm.

Brown et al.'s criterion (i) illustrates the limitations of their approach in the present context: a canonical periphrasis involves canonical functional syntax, i.e. the construction is not syntactically irregular. Yet syntactic irregularity is key evidence for morphological status in many situations. Brown et al. do not deny this, but they argue that any periphrastic construction identifiable by means of syntactic irregularity is not a canonical instance of periphrasis. Criterion (ii) means that canonical periphrasis is an obligatory means of expressing an inflectional grammatical feature (similar to Bonami \& Samvelian's 2015 criterion 'obligatoriness'). Criterion (iii) has been discussed above, in relation to Ackerman \& Stump's non-compositionality criterion, and criterion (iv) is essentially the same as Ackerman \& Stump's criterion I.

A valuable discussion of the diversity of periphrastic expression is provided by Bonami \& Samvelian (2015) in their analysis of Persian verbal constructions. Modern Persian makes use of five different multiword verbal constructions; Bonami \& Samvelian (2015) show that different formal analyses are appropriate for different constructions.

The passive voice can only be expressed constructionally in Persian, i.e. there are no synthetic passive voice forms. Bonami \& Samvelian (2015) argue therefore, in line with Ackerman \& Stump's (2004) criterion I, that the Persian passive construction is not a periphrasis, because voice is not an inflectional category in Persian; in addition, the configuration of the passive construction is an independently existing syntactic configuration in Persian, i.e. there is no irregular or non-standard aspect to the construction in syntactic terms. ${ }^{6}$ On the other hand, Bonami \& Samvelian (2015) argue that the Persian perfect construction is periphrastic. Most forms of the perfect in Persian are multiword, but the present perfect is synthetic, and also syncretic with the past indirect perfective. The relevant parts of the Persian verbal paradigm are shown in (4), from Bonami \& Samvelian (2015: 357), based on the verb xaridan 'buy'.

(4)

${ }^{6}$ This would be a positive feature of a canonical periphrasis, according to Brown et al. (2012). 


\begin{tabular}{|c|c|c|c|}
\hline & BOUNDED & UNBOUNDED & PERFECT \\
\hline PRESENT & - & $\begin{array}{l}\text { simple present } \\
\text { mi-xar-ad }\end{array}$ & $\begin{array}{l}\text { complex present } \\
\text { xarid-e-ast }\end{array}$ \\
\hline PAST DIRECT & $\begin{array}{l}\text { bounded past } \\
\text { xarid }\end{array}$ & $\begin{array}{l}\text { unbd. past } \\
\text { mi-xarid }\end{array}$ & $\begin{array}{l}\text { complex bounded past } \\
\text { xarid-e bud }\end{array}$ \\
\hline PAST INDIRECT & $\begin{array}{l}\text { complex present } \\
\text { xarid-e-ast }\end{array}$ & $\begin{array}{l}\text { complex unbd. past } \\
\text { mi-xarid-e-ast }\end{array}$ & $\begin{array}{l}\text { complex perfect } \\
\text { xarid-e bud-e-ast }\end{array}$ \\
\hline SUBJUNCTIVE & \multicolumn{2}{|l|}{$\begin{array}{l}\text { simple subjunctive } \\
\text { be-xar-ad }\end{array}$} & $\begin{array}{l}\text { complex subjunctive } \\
\text { xarid-e bâš-ad }\end{array}$ \\
\hline
\end{tabular}

Since the present perfect is synthetic and syncretic with another part of the paradigm, there must exist slots in the Persian verbal paradigm for the present perfect. But this entails that the perfect is an inflectional category in Persian, i.e. that it participates in the feature system of the verbal paradigm, and consequently the perfect forms which are not synthetic do fill slots in the Persian verbal paradigm (as shown in 4), and hence are periphrastic. Bonami \& Samvelian's analysis of the Persian passive and perfect constructions illustrate the crucial importance of paradigms to the status of a construction. As we will see, the existence (or otherwise) of synthetic forms alongside multiword constructions is one of the most important pieces of evidence for the status of the Sanskrit periphrastic future.

Bonami \& Samvelian (2015) propose a formal analysis of periphrasis within the framework of Head-driven Phrase Structure Grammar (HPSG: Pollard \& Sag 1994, Sag et al. 2003). ${ }^{7}$ They propose that in the case of a periphrastic slot in a verbal paradigm, the form of the verb is specified as a form of the copula, but with an additional subcategorization for e.g. a participle form of the verbal lexeme concerned. That is, in terms of the verbal paradigm, each slot is filled by at most one word, but in the case of a periphrastic slot, the word which fills the slot is not a form of the lexeme concerned, but a form of the copula (or other functional verb). This form appears with a subcategorization requirement such that it must appear alongside a (e.g.) participial form of the verbal lexeme in the syntax. Bonami \& Samvelian (2015) argue that their approach has a number of advantages: it is a kind of syntactic exponence, but is not phrasal in the sense that it is licensed by word-level properties; in addition, it is a fundamentally morphological rule, which can interact with other morphological rules, but which results in a multiword exponent with a syntactic relationship between the words.

Stump (2012: 130-136) provides a formal analysis of the Sanskrit periphrastic future based on the proposals of Bonami \& Samvelian $(2009,2015)$. There are a number of questions that might be raised in regard to the details of Stump's analysis, but only one issue will concern us here: Stump's analysis depends first and foremost on the assumption that the Sanskrit periphrastic future is a true periphrasis in the sense defined in this section. If it is not, then a wholly different analysis will be required. It is this issue to which we now turn.

\section{The SANSKRit PERIPHRASTIC FUTURE: THEORY AND PRACTICE}

In this section I present the main facts regarding the form and function of the periphrastic future, contrasting the standard account with the more complex evidence of actual usage. Before doing so, I provide a summary of the historical development of the Sanskrit language, in order to introduce the main varieties and periods of Sanskrit, the differences between which will be important below.

\footnotetext{
${ }^{7}$ Their proposal, originally in Bonami \& Samvelian (2009), has also been employed by e.g. Stump \& Hippisley (2011) and Popova \& Spencer (2012); it is further developed by Bonami \& Webelhuth (2012) and Bonami (2015).
} 
The Rgveda preserves the oldest substantial corpus of Indo-Aryan, composed perhaps c. 15001200 B.C. Its language undoubtedly reflects an already somewhat archaizing sociolect, utilized by religious poets during the migration of the Indo-Aryans across the Indus valley into the Ganges plains. Even in the Rgveda, there is evidence of non-Sanskritic dialects in certain word forms, attesting to a range of Indo-Aryan dialects contemporary with Rgvedic Sanskrit, and there is also some evidence of diachronic development within the Rgveda, the tenth and latest book appearing in several respects linguistically more similar to the Sanskrit of the Atharvaveda. The Atharvaveda is the second oldest collection of Sanskrit works, and is clearly later than the core of the Rgveda, but earlier than the majority of the next oldest body of literature, Vedic Prose. Vedic Prose is a cover term for a huge body of diverse and chronologically varied literature, which is all in one way or another concerned with describing, interpreting, and explaining Vedic ritual practices, as well as the earlier Vedic texts (including Rgvedic texts) used in Vedic rituals. There are three main divisions of Vedic Prose text: Brāhmaṇas, Āraṇyakas and Upanișads. The Brāhmaṇas are in general older than the Āraṇakas, and the Āranyakas older than the Upanișads, but these three stages represent a gradual evolution of a single genre (mainly towards increasingly esoteric concerns), and it is not always possible to securely distinguish them. The dating of all early Sanskrit literature is problematic, but Gonda (1975: 360) tentatively suggests that the main Brāhmana texts may date to between the 10th and 7 th centuries B.C. ${ }^{8}$

The end of the Vedic period merges into what may be called the Post-Vedic period. A variety of texts exist which are not Vedic, but which are not written in standardized 'Classical' Sanskrit. These include the Vedānga, ancillary texts to the Vedic corpus, and most importantly the two great Sanskrit epics, the Mahābhärata and the Rāmāyana. The origins of the Sanskrit epics lie in Proto-IndoEuropean pre-history (Watkins 1995), but the texts as we have them are unlikely to contain material much older than c. 400 B.C., and reached their final form by around 400 A.D. (Brockington 1998: 25-26). The Sanskrit epics, as well as other post-Vedic literature, are written in a form of Sanskrit which shows evidence of a slightly different dialect mix from the earlier Vedic Prose period, and which is closer to that of Classical Sanskrit. There are even certain features of Epic Sanskrit, and other closely related post-Vedic dialects, which do not continue developments found in Vedic Prose, but show a different path of development from the earlier Rgvedic Sanskrit situation. ${ }^{9}$ That is, there is evidence that the Vedic Prose dialect/sociolect represents not the direct precursor of later post-Vedic Sanskrit, but more of a separate branch which developed in its own ways and was not directly continued in post-Vedic times. The subsequent development of the Sanskrit language is fundamentally tied to Pānini, whose grammatical work the Asțādhyāyz became the basis of a standardized learned language. 'Non-standard' Sanskrit survived into the early centuries A.D., but ultimately Sanskrit became a fixed language, learned and used with reference to a prescriptive grammatical tradition.

\footnotetext{
${ }^{8}$ The main chronological divisions of Vedic literature are controversial. Narten (1968: 115, fn. 13) distinguishes five periods: the Rgveda; the Atharvaveda and Yajurvedic mantras; prose portions of the Yajurveda saṃitās; most Brāhmaṇa prose, including a few earlier Upanișads; late Vedic prose, including the Gopatha Brāhmaṇa, Āraṇyakas and later texts. Kulikov (2013) divides the Vedic period broadly into three: the Early Vedic period, including the Rgveda and Atharvaveda; the Middle Vedic period, including the Yajurveda mantras and early Brāhmaṇas, the Late Vedic period, including the late Brāhmaṇas and Āranyakas; Kulikov classifies the Upaniṣads as Early Post Vedic.

${ }^{9}$ For example, Jamison (1990) shows that in respect of the development of the predicated past passive participle, some changes between Rgvedic and later Vedic are not found in Epic and Classical Sanskrit, rather Vedic Prose and Epic/Classical Sanskrit show divergent developments from the Rgvedic situation. Similarly, Renou (1938: 124) argues that accusative object government by nouns in -tr- in Epic and Classical Sanskrit is a feature inherited from Rgvedic Sanskrit which was lost in Vedic Prose.
} 


\subsection{Theory}

The Sanskrit periphrastic future is known to have developed from an agent noun formation in -tr-. In the earliest Sanskrit text, the Rgveda, there are two agent noun formations in -tr-, one accented on the root, -tṛ-, the other accented on the suffix, -tṛ́-, e.g. kárț̣- 'maker' and kartị́- 'id.'. The differences between these two formations have been discussed by a number of authors, most recently Kiparsky (2016). Semantic differences are hard to pin down, but there is at least one relatively clear syntactic distinction: logical objects of nouns in -tr- usually appear as dependents in the accusative case, the same case as verbal objects, whereas logical objects of nouns in -tŕ- occur overwhelmingly in the genitive case, the standard case for nominal dependents. There is some disagreement over which agent noun gives rise to the periphrastic future. On the one hand, the standard accentuation pattern of the periphrastic future corresponds with the accentuation of -tŕ-; on the other hand, it is tempting to see a connection between the verbal object government of -tr- and the verbal construction of the periphrastic future. In addition, -tr- begins to drop out of use in the post-Rgvedic period, and shows barely any productivity in early Vedic Prose, at exactly the period where the periphrastic future first appears. The issue has been recently discussed by Stump (2012: 121-130), who follows the view of Gonda (1957) that both accentual types contributed to the periphrastic future. Stump makes the important point that verbal properties of the periphrastic future, including accusative object government, can unproblematically have developed subsequent to the reanalysis of the agent noun formation as a verbal formation, so the similarity with the accusative object government of -tr- may be coincidental. I therefore assume for the present that the periphrastic future developed, at least formally, from -tṛ́-. The regular declension of the agent noun in -tŕ- is given in ex. $5 .^{10}$

(5) Paradigm of kartị- 'maker':

\begin{tabular}{|c|c|c|c|}
\hline & Masculine & Feminine & Neuter \\
\hline Nom.sg. & kartá & kartrí & karț̣́/kartár \\
\hline Acc.sg. & kartáram & kartrím & kartị́ \\
\hline Ins.sg. & kartrá & kartryấ & kartrá(/kartṛnāā) \\
\hline Dat.sg. & kartré & kartryái & kartré(/karț̣ne) \\
\hline Abl./gen.sg. & kartúr & kartryáh & kartúr(/kartŕnah) \\
\hline loc.sg. & kartári & kartryắm & kartári(/karț̣́ni) \\
\hline voc.sg. & kártar & kártrī & kártṛ/kártar \\
\hline Nom./acc.du. & kartărau & kartrí (later kartryàu) & kartṛn̄̄ \\
\hline Ins./dat./abl.du. & kartŕbhyām & kartríbhyām & kartŕbhyām \\
\hline Gen./loc.du. & kartróh & kartryóḥ & kartróḥ(/kartụ́ṇoḥ) \\
\hline voc.du. & kártārau & kártrī (kártryau) & kártṝ̣̄ \\
\hline Nom.pl. & kartărạ̣ & kartríḥ (later kartryàḥ) & karț̣ni \\
\hline Acc.pl. & kartŕn & kartríh & kartŕni \\
\hline Ins.pl. & kartṛ́bhih & kartríbhih & kartṛbhih \\
\hline Dat./Abl.pl. & kartŕbhyah & kartríbhyah & kartŕbhyah \\
\hline Gen.pl. & kartịnām & kartrínāam & karț̣nām \\
\hline Loc.pl. & kartŕṣu & kartríṣu & kartŕṣu \\
\hline Voc.pl. & kártārah & kártrīh (later kártryah) & kárț̄ni \\
\hline
\end{tabular}

\footnotetext{
${ }^{10}$ The full paradigm is specified in grammatical works, but several forms, in particular the neuter, are extremely rare in texts.
} 
The periphrastic future is evidently based on a construction involving nominative masculine forms of the agent noun together with a copula. The present indicative of the copula $\sqrt{ }$ as 'be' is given in (6), and the active paradigm of the periphrastic future is given in (7).

$\begin{array}{llll} & \text { sg. } & \text { du. } & \text { pl. } \\ \text { 1. } & \text { ásmi } & \text { svás } & \text { smás } \\ \text { 2. } & \text { ási } & \text { sthás } & \text { sthá } \\ \text { 3. } & \text { ásti } & \text { stás } & \text { sánti }\end{array}$

$\begin{array}{llll} & \text { sg. } & \text { du. } & \text { pl. } \\ \text { 1. } & \text { kartásmi } & \text { kartásvas } & \text { kartásmas } \\ \text { 2. } & \text { kartási } & \text { kartásthas } & \text { kartástha } \\ \text { 3. } & \text { kartá } & \text { kartárau } & \text { kartáras }\end{array}$

The 1sg. and 2sg. forms of the periphrastic future are unproblematic: the nom.sg.masc., e.g. kartá, followed by e.g. the $1 \mathrm{sg}$. copular ásmi, results in the sequence kartá asmi (with the copula regularly unaccented in a main clause), which by the regular rules of Sanskrit sandhi surfaces as kartásmi. The third person forms are also as expected: the copula is usually null in the third person, so the form of the periphrastic future is identical with that of the nom.masc. agent noun, in the appropriate number. Note this means that in the third person, the periphrastic future is only periphrastic underlyingly, since it surfaces as a single word. The $1 \mathrm{du}$., $1 \mathrm{pl} ., 2 \mathrm{du}$. and $2 \mathrm{pl}$. forms are more problematic: they appear to derive from a sequence of nominative singular masc. agent noun followed by the appropriate form of the copula. That is, in these person/number combinations, the agent noun part of the periphrasis does not display the appropriate number agreement.

There is evidence that the $1 \mathrm{sg}$. and $2 \mathrm{sg}$. forms consist of two distinct word forms, even though this is obscured in the paradigm above by the application of sandhi. So, words may occasionally intervene between the agent noun and the copula, e.g. kartā cāsi 'and you will make' at Rāmāyaṇa 7.70.8b. Stump (2012: 111) assumes that the same applies to the 1du., 1pl., 2du. and 2pl. forms, e.g. 1 du. kartásvah is merely the sandhi form of a two word sequence kartá svah. However, I am aware of no examples of $1 / 2 . \mathrm{du} / \mathrm{pl}$. forms ever being separated. In manuscripts and printed texts, where the nāgarī script permits a distinction to be made between a single word such as kartấsvah and a two word sequence kartâ svah, the standard convention is to write such forms as single words. ${ }^{11}$ The question is an important one, not only because it affects Stump's formal analysis of the periphrastic future, but more importantly because the status of these sequences is highly relevant to the question of whether this really is a periphrasis at all. The matter will be discussed in detail below, but for present purposes I assume that the $1 / 2 . \mathrm{du} / \mathrm{pl}$. forms are single morphological words. Note this means that only two of the nine cells in the paradigm are periphrastic in the sense of being realised by more than one word. ${ }^{12}$

\footnotetext{
${ }^{11}$ The only examples of separated forms I have found are in the transliterated edition of the Bhattikāvya by Fallon (2009). However, this is clearly an (erroneous) artificiality of the transliteration conventions used in the Clay Sanskrit Library series; no nāgarī editions of the Bhattikāvya split the relevant forms, including the edition on which the Sanskrit text of Fallon (2009) is based.

${ }^{12}$ It is worth noting that the single word status of all person/number combinations of the periphrastic future is assumed in Pānini's Aștādhyāyzi. Pānini treats the periphrastic future as an inflectional verbal formation, formed by means of an underlying tense suffix $-t \bar{a}(S)$-, to which person/number suffixes are added (in some person/number combinations the $-s$ - of -tās- is dropped before the suffix, and while some endings are the same as for other tenses, e.g. 1sg. active -mi, others are specific to this paradigm, e.g. 3pl. -rah). For Pānini, even the 1sg. and 2 sg. forms are synthetic: so the 1sg. is a single word analysed as e.g. kar-tās-mi. This means that for Pānini, and in strictly Pāninian Sanskrit more generally, the 'periphrastic future' is undoubtedly paradigmatic, but not periphrastic. Pānini's analysis is followed e.g. by Cardona (2003: 130-131).
} 
Beside the active paradigm, there exists also a mediopassive paradigm. The very existence of mediopassive forms is significant for the status of the construction. The independent copula does not have mediopassive forms, so there is no way that the first and second person forms of the mediopassive paradigm can derive from a syntactic sequence of agent noun plus copula. Rather, the mediopassive has evidently been formed analogically after the active, on the basis of the finite present indicative. For example, the four-part analogical comparison 1du. pácā-vah 'we two cook' - kartás-vah 'we two will make' : pácā-vahe 'we two cook for ourselves' - X produces kartâs-vahe 'we two will make for ourselves'.

$\begin{array}{llll} & \text { sing. } & \text { du. } & \text { pl. } \\ \text { 1. } & \text { kartáhe(/kartáse) } & \text { kartásvahe } & \text { kartásmahe } \\ \text { 2. } & \text { kartấse } & \text { kartásathe } & \text { kartádhve } \\ \text { 3. } & \text { kartấ } & \text { kartấrau } & \text { kartấrạ }\end{array}$

The only form in the paradigm which is not simply based on the active is the $1 \mathrm{sg}$. in -he. The expected ending is -se, which is attested once in early Vedic Prose (ex. 33 below), but is identical with the $2 \mathrm{sg}$. The ending -he is based on an alternative means of expressing the $1 \mathrm{sg}$. active, using the 1sg. personal pronoun ahám in place of the copula (or alternatively marking person/number using the pronoun, together with a null copula); for example, kartâham 'I will make', sandhi form of kartá aham. The ending -am is identical to the 1sg. imperfect active ending, e.g. ápacam 'I cooked', which in class 1 verbs has a corresponding middle in -e, e.g. ápace 'I cooked', and it is on this basis that kartáhe was created.

The sequence kartáham 'I will make' exemplifies what is usually taken to be an alternative means of forming active forms of the periphrastic future, strictly irregular but well-attested, particularly at certain periods (as we will see below). In particular, the 1/2.du/pl. active forms may be formed using the nominative of the agent noun and either the relevant personal pronoun or a form of the copula separated from the agent noun; crucially, this formation requires the agent noun to appear in the correct number, e.g. 1pl. kartárạ̣ smạ̣ or kartáro vayám 'we will make' in place of kartásmaḥ. I refer to such forms as 'analytic' forms of the periphrastic future, in opposition to 'synthetic' forms such as $1 \mathrm{pl}$. kartăsmặ.

Even more clearly than the active 1/2.du/pl., the first and second person mediopassive forms cannot be analysed as two word sequences, since mediopassive copular forms like *ase or *svahe do not exist. ${ }^{13}$ We are therefore dealing with single morphological words, and the mediopassive paradigm contains no two-word sequences. In the third person, the lack of explicit copula in the active meant that distinctly mediopassive forms could not be analogically created, so the middle forms are identical to the active.

\subsection{Practice}

Stump (2012) discusses the status of the Sanskrit periphrastic future in relation to the criteria for periphrasis proposed by Ackerman \& Stump (2004). He concludes very clearly that the construction is a periphrasis in the technical sense defined above. And even just on the basis of the paradigms introduced above, in particular the mediopassive, that seems to be the most obvious conclusion. However,

\footnotetext{
${ }^{13}$ Stump (2012) does not address this question explicitly, and does not deal with the middle in the formalization he provides, but in citing examples he uses the same mark to distinguish stem and suffix with the mediopassive as with the active, which is the same mark used to indicate sandhi conjunction, e.g. yaștāasmahe 'we will sacrifice' beside gantāaasmi 'I will go', implying that he takes the mediopassive forms as two word sequences.
} 
all of the evidence in favour of treating the periphrastic future as a true periphrasis is problematic in one way or another.

Before addressing Stump's arguments for the paradigmatic status of the periphrastic future, it is necessary to address one argument which could speak against such a status. Stump (2012: 116) states that "there are occasional instances in which the deverbal noun in a periphrastic future construction is a nominal derivative in -in rather than in -tr?", giving the following example: ${ }^{14}$
surāsura-vimardo
bhāvī
god-demon-conflict.NOM.SG.M be.DERIV.NOM.SG

'There will be a conflict between the gods and demons.' (Vikramorvaśî V)

It is hard to see how the periphrastic future could be a paradigmatic formation and yet optionally make use of different derivatives in its formation. If the form in question were a genuine instance of the periphrastic future, it would surely prove that the periphrastic future was a syntactic construction involving some (morphologically unspecified) agent noun/adjective formation, i.e. that the construction was not a properly systematized or grammaticalized periphrasis. However, all the example shows is that -tr- is not the only agent noun/adjective which could display future sense. It is worth noting that the example as given by Speyer and Stump may not be a full sentence, and the form in question may not be a clausal predicate. ${ }^{15}$ The text has a number of variant readings, but as given by Shankar (1879: 159) the text runs as follows:

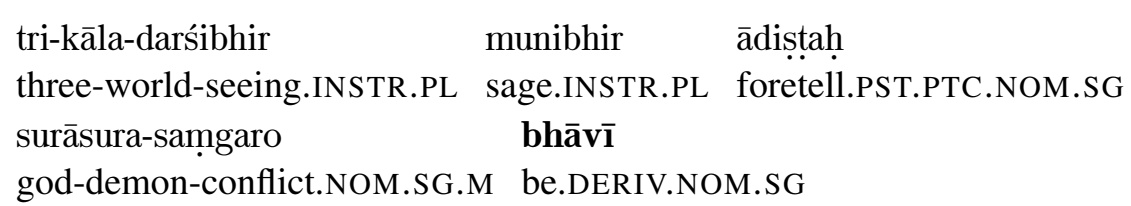

'The sages that behold the three worlds have foretold of the coming battle between gods and asuras.' (Vikramorvaśī V, p. 159)

Crucially, there is no iti at the end of the clause, and ādistạ is masculine, meaning that surāsurasamgaro bhāvī cannot be read as quoted speech and consequently bhāvī cannot be taken as a main predicate. Rather surāsura-samgaro is the subject, and bhāvī must be interpreted adjectivally, with the sense 'coming, future'. ${ }^{16}$

Turning now to arguments in favour of the periphrastic status of the construction, the first argument made by Stump (2012: 112) relates to Ackerman \& Stump's (2004) criterion of non-compositionality: "because the copula in the Sanskrit periphrastic future construction is inflected for the present tense, this construction is non-compositional". As discussed above, non-compositionality is a problematic criterion for periphrasis: uncontroversially syntactic idioms are non-compositional, and whether a construction is non-compositional depends on a prior account of morphological features and their combination. Most obviously, if the tense value PRESENT is taken to be the unmarked default, then the future tense of the construction does not necessarily imply non-compositionality. The default status of present tense in Sanskrit is a more than reasonable assumption, given the omissability of the present tense copula (as evidenced in the paradigm of the periphrastic future itself). Even if PRESENT is not

\footnotetext{
${ }^{14}$ Stump gives the second word as bhāvi, which must be an error: he takes the example from Speyer (1886: 258), who gives bhāvī as expected.

${ }^{15}$ Note that Speyer (1886: 258) gives this example merely as an instance of other suffixes indicating a future sense, not necessarily as an instance of the periphrastic future per se; the latter claim is Stump's.

${ }^{16}$ Some variant readings do end the clause with iti, and read neuter ādiștạ for ādiștah, so the reading is possible, but not necessary.
} 
taken as the unmarked tense value, this does not necessarily exclude its appearance in the periphrastic future, since it would have to be clearly established that the latter expresses specifically future tense, rather than say a posterior aspect or a modal sense. For example, Lowe (2015) argues that the paradigmatic Rgvedic Sanskrit future in -sya- in fact expresses present tense in combination with posterior aspect, which results in reference to a future event from the perspective of the present. Setting aspect aside, future tense is often difficult to disentangle from modality (see Ultan 1978). If the 'future' sense of the periphrastic future could be interpreted modally, then it would not clash with present tense.

Whatever the grammatical feature expressed by the periphrastic future, however, whether future tense or something else, there must be an account of where it comes from. Since it is not expressed by the copula, it must be expressed by the agent noun. Despite the agent noun not being the 'head' of the construction in Bonami \& Samvelian's (2015) terms, such a feature could be inherited by the construction as a whole if the present tense of the copula is unmarked. However, it is usually assumed that the agent noun (either accentual type) does not have future or future-like reference. The following are particularly clear examples of -tŕ- from the Rgvedic period.

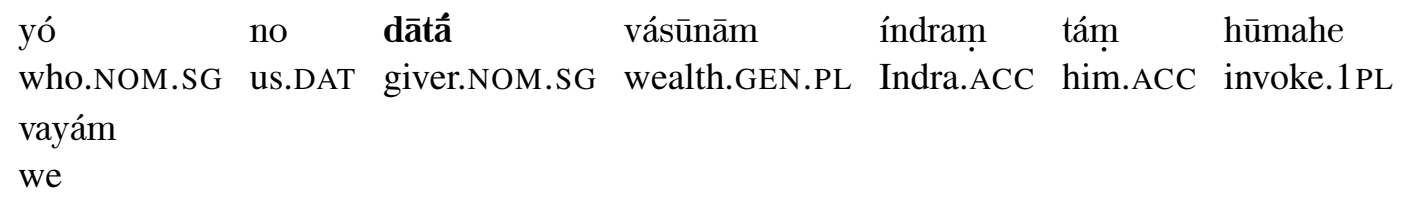

In the Rgveda, it is uncertain whether future sense is necessarily shown by either -tr- or -tŕ-. The recent translation by Jamison \& Brereton (2014) interprets some examples of both types with a future sense, e.g. prayantŕ- at RV 1.51.14d, and gántr- at RV 1.9.9d. However, all such examples can also be interpreted with a more timeless sense, referring to a characteristic action (usually of a god) which can be expected to continue into the future. For later periods, however, future sense is often taken as the prime criterion for distinguishing the periphrastic future from the agent noun in syntactically ambiguous cases. For example, the nom.sg.masc. upanidhātá occurs at ŚB 1.1.2.18, governing an accusative object and functioning as the main predicatory element in the clause:
pūṣá bhāgadughó 'śanam pāníbhyām upanidhātá
P.NOM portion-distributor.NOM.SG food.ACC.SG hand.INSTR.DU placer_before.NOM.SG
'Pūṣan is the distributor of portions, he places food before (the gods) with his hands.'
(ŚB 1.1.2.18)

In all syntactic respects this looks like a good example of the periphrastic future. However, the form is noted by Gaedicke (1880: 187) and Renou (1938: 121) as an example of the agent noun in -tŕ-, unexpectedly governing an accusative object, rather than as an instance of the periphrastic future. The only possible rationale for this analysis is the lack of clear future sense. Yet at the same period, and later, there are examples of agent nouns in -tŕ- which unambiguously show a future or future-like sense. This is recognized by Renou (1961: 491), who grants -tr- a "nuance future" in some instances. For example, at ŚB 10.1.1.4 abhinetŕ- 'bringer' is used with a clear sense of intentionality. 

(14) tád yát tátra yájuh purástād éti abhinetaiva tád so when there Yajus.NOM.SG in_front go.3SG bringer.NOM.SG=indeed that.NOM.SG eti go.3SG

'So when the Yajus goes in front here, it goes so as to fetch (something).' (ŚB 10.1.1.4)

The agent noun is not a predicate here, but is used appositionally, so this cannot possibly be an instance of the periphrastic future. In later Epic Sanskrit, there is one example of an accusative form of the agent noun with future sense, a form of udyantr- 'bearer' at MBh. 12.29.38:
(15)
nodyantāram dhuram tasya kạ̣ cin mene prajāpatị̣ not=bearer.ACC.SG burden.ACC.SG that.GEN.SG anyone.ACC.SG think.PF.3SG P.NOM.SG
'Prajāpati thought that no one would be able to bear the burden of that.' (MBh. 12.29.38ab)

The agent noun appears as the predicate inside the indirect discourse governed by mene 'he thought'. It is almost as if the periphrastic future has been converted into the accusative so as to be licensed within the indirect discourse. However, this is not a grammatical possibility in Sanskrit: the periphrastic future exists only in the forms provided in (7) and (8), based on the nominative of the agent noun.

In ex. (16), the context implies a sense of possibility or ability: the addressee (Kumbhakarna) has not yet slain (and indeed will not slay) the referent of tasya (Rāma). The form nihantāsti would be irregular for a periphrastic future, since the copular should be absent in the 3sg., and the genitive object further suggests that we are dealing with the agent noun. Yet a simple agent noun interpretation, with no modal or future sense, would imply that the slaying had already taken place ('you alone are his slayer' > 'you alone have slain him'). In this case, then, a clear form of -tr- must be interpreted with at least something approaching future sense. ${ }^{17}$

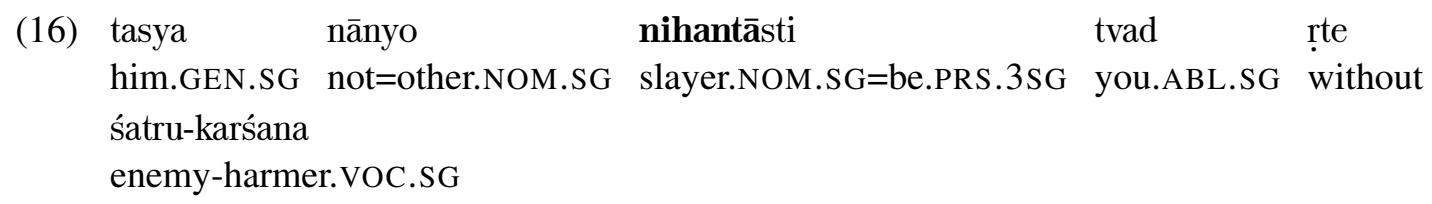

'There is no one apart from you who can slay him, O harmer of enemies.' (MBh. 3.270.25cd)

In some instances it becomes almost impossible to tell the difference between agent noun and periphrastic future. So, Skt. ced 'if' can be construed with the future ('if he will...') or with a noun ('if he is...'). At MBh. 12.228.5 the form anudraștā occurs as the main predicate in a clause headed by ced. The form governs a genitive case object, which is irregular, but not impossible, for the periphrastic future, but regular for the agent noun. It is an open question whether this should be interpreted as a periphrastic future because of the future sense inherent in the clause, or as an agent noun because of the genitive government (the future sense deriving entirely from ced).

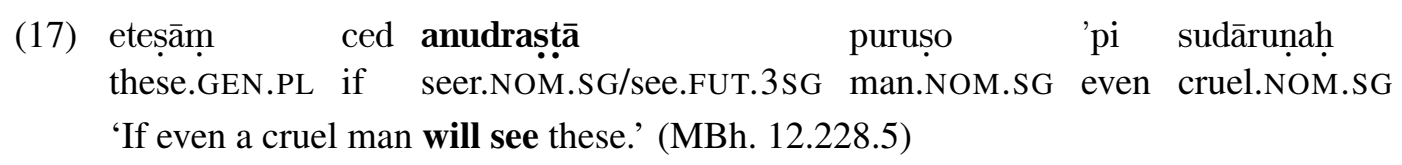

\footnotetext{
${ }^{17}$ A similar example appears at MBh. 6.103.92. This use of -tr- to refer to someone who should or may do something, but who has not yet, is paralleled even in the Rgveda, e.g. at RV 1.32.14 where yātŕ- refers to a potential, rather than actual, avenger.
} 
Finally, the semantic interpretation of a form is often a subjective matter. For example, the instance of tyaktr- 'abandoner' in ex. (18) is listed by Whitney (1896: 91) as an example of transitive -tr- which cannot be taken as a periphrastic future. However, the form is a predicate in its clause, and could, formally, be a periphrastic future, so the only criterion on which to reject a future interpretation is semantic. In context, the sense of the form is not a certain future, but a potential one: it is not that they will necessarily lose their lives, but that they are willing to do so. But since the future is inherently uncertain, this potential sense cannot be excluded for the periphrastic future.

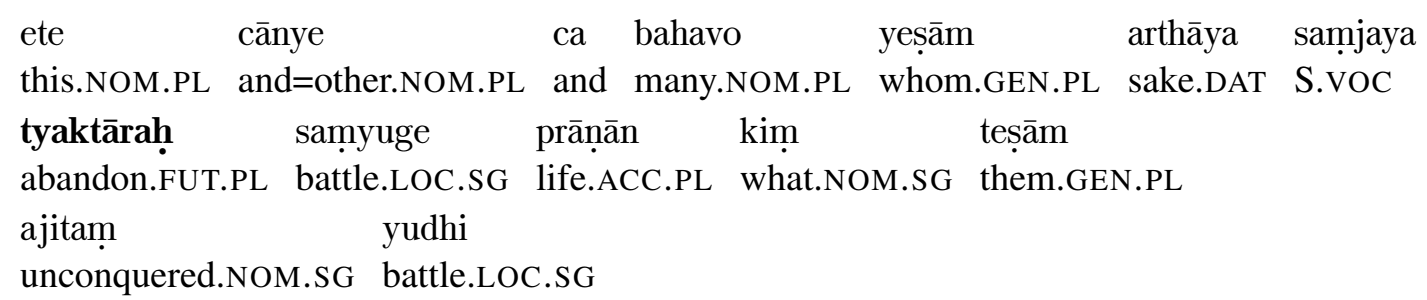

There are therefore some certain examples of the agent noun in -tŕ- (later -tr-) with a future, or at least future-like, sense. ${ }^{18}$ And given the potential ambiguity between agent noun and periphrastic future in some contexts, there may be many more which have been incorrectly assigned to the future. Returning to the non-compositionality of the periphrastic future, then, it cannot be denied that the agent noun may have a future, or future-like, sense, and thus there is nothing to prevent us from assuming that the periphrastic future construction is fully compositional in regard to its tense reference.

There is a second way in which the periphrastic future might be non-compositional: the singular forms of the agent noun in the $1 / 2 . \mathrm{du} / \mathrm{pl}$. forms do not reflect the number of the construction. Here there are three difficulties with assuming non-compositionality: firstly, if singular number is default, there is no clash; secondly, following Bonami \& Samvelian (2015), the agent noun is not the head of the construction, so its number feature is not necessarily expected to be a feature of the construction; thirdly, the problem only arises if one assumes, following Stump (2012), that the 1/2.du/pl. are two word sequences, rather than single morphological words. As argued above, there is no positive evidence that a form such as kartásvah is anything other than a single word. As a single morphological word, kartásvah is clearly based on the singular form of the agent noun, but need not itself express a SINGULAR feature.

A second piece of evidence for the periphrastic status of the periphrastic future is its accusative object government, which according to Stump (2012: 112) shows that we are not dealing with an "ordinary predicate nominal construction". It is true that for the most part, nouns in Sanskrit cannot govern objects in the accusative, and that accusative object government is the preserve of verbal formations. However, there are a subset of lexical noun and adjective categories in Sanskrit which can govern accusative objects. ${ }^{19}$ The phenomenon may be unusual, but is not irregular in Sanskrit terms, and is licensed by the authoritative Sanskrit grammarian Pānini, whose grammar the Aștâdhyāyz became the prescriptive basis for the Classical language. One of the transitive noun formations in Sanskrit is the agent noun in -tr- in the Rgveda, which is found governing accusative objects in more than one quarter of its occurrences. In later Sanskrit too, -tr- does occasionally govern the accusative, as illustrated by some of the examples given above. In the following example, the four transitive forms are unambiguously agent nouns, since the copula (which occurs in the previous verse) is past tense:

\footnotetext{
${ }^{18}$ Lowe (2017) discusses several additional examples not given above.

${ }^{19}$ See Lowe $(2016,2017)$ and further on this phenomenon in related languages Lowe (2013a,b, 2014).
} 
(19)

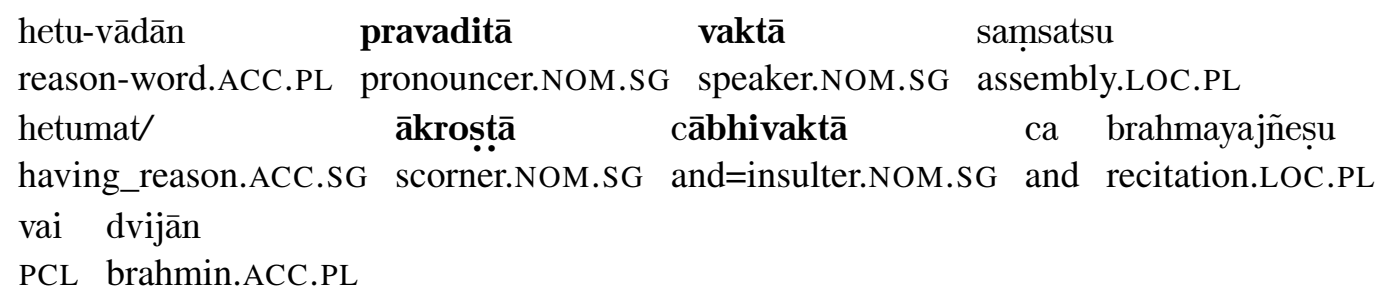

'[I was... ] a pronouncer of words based on reason (rather than faith), a speaker of reason/reasonably in assemblies, a scorner and insulter of brahmins at recitations.'

(MBh. 12.173.46)

Besides -tr-, a number of other noun and adjective categories can govern objects in Sanskrit at all periods. Most categories are agent nouns or agentive adjectives, but it is even found occasionally with abstract nouns, for example the noun jighāmsāa- 'desire to slay':

(20) sa
sa roṣa-vaśam
āpannah
karṇam eva
he.NOM.SG anger-power.ACC.SG
obtained.NOM.SG K.ACC.SG indeed
jighāmsayā
avaikșata
viṿ̂ttābhyāṃ
netrābhyāṃ kuru-puṃgavah
desire_to_slay.INS.SG look.IMF.3SG whirling.INS.DU eye.INS.DU K.-bull.NOM.SG

'Filled with rage and through a desire to slay Karna, the bull of the Kurus looked at (him)

with whirling eyes.' (MBh. 4.54.17)

Thus object government cannot be taken as sufficient evidence for a verbal formation in general, nor can object government be taken as evidence for a periphrastic future construction in any particular instance. At the same time, there are passages in which a form traditionally assigned to the periphrastic future (primarily for semantic reasons) governs an object in the genitive case (noted by Stump 2012: 116). In ex. (21), the future context is very clear: the sentence is one of a sequence of threats; it is immediately followed in the next verse by a clear periphrastic future with accusative object hantāsmi... tvām 'I will kill you'.

(21) kartāhạ̣ karmaṇas tasya kuru kāryāṇi sarvaśạ do.FUT=1SG deed.GEN.SG this.GEN.SG do.IMP.2SG to_be_done.ACC.PL completely

'I will do the deed (of killing you); so finish what you need to do (before then).'

(MBh. 2.68.40cd)

Hara (1987: 210) notes this as the only instance of the future governing the genitive in the MBh., explaining it as "a remnant of the old nomen agentis". However, there are a number of other instances which can be so interpreted. In ex. (22), the periphrastic future, prativaktāsmi, governs a genitive; the future context is relatively clear, in particular given the synthetic future form in the second line.

(22) avahāsasya vo 'syādya prativaktāsmi pāṇ̣avāḥ/ gamisyatha

insult.GEN.SG you.GEN.PL this.GEN.SG=today answer.FUT.1SG P.VOC.PL go.FUT.2PL

hatāḥ sadyah sapāñāāā yamakṣayam

slain.NOM.PL immediately with-P.NOM.PL underworld.ACC.SG

'I will answer back this insult of yours today, O Pāṇ̣avas: together with the Pāñcālas you will go slain to the underworld right away.' (MBh. 9.31.44)

Genitive government is also clear in the Mahābhārata with apparent periphrastic futures at MBh. 9.31.44 (avahāsasya...prativaktāsmi), MBh. 7.39.6 (śāsitāsmi...te), MBh. 3.173.19 (draștā tavāsmi), MBh. 8.46.37 
(aham hantā phalgunasya). All the forms in question are main clause predicates, and have future sense, yet they govern objective genitives as if they were nouns.

Except with a few classes of verbs, such as verbs of ruling, the genitive is not a possible object case. Thus the fact that apparently clear cases of the periphrastic future can govern objects in the genitive, when corresponding present, perfect, future etc. finite forms would necessarily govern the accusative, raises a serious question mark over the status of the formation as a verbal construction. Since accusative object government is not sufficient evidence for a verbal construction, and genitive government is relatively good evidence against a verbal construction, we can at least conclude that the evidence of object government is not telling either way.

Further evidence cited by Stump (2012: 113-114) in favour of treating the periphrastic future as a verbal formation, distinct from the agent noun, is the existence of forms such as $3 \mathrm{sg}$. vraștât 'it will rain' and 3pl. bhavitârah 'they will become'. Stump claims that forms such as these prove that the interpretation of the formation cannot be that of an agent noun, since the verbs $\sqrt{ } v r \underline{s}$ 'rain' and $\sqrt{ } b h \bar{u}$ 'become' are not agentive and do not form agent nouns; the former, in particular, takes an expletive subject (according to Stump 2012). However, the term 'agent noun' is a traditional term, which is something of a misnomer in modern linguistic terms. 'Agent' in 'agent noun' really means 'subject': the characteristic of the formation is that it denotes the subject of an event denoted by the verb from which it is derived, and it is not restricted to agents in semantic role terms. ${ }^{20}$ There are countless examples of agent nouns which refer to roles other than agent; for example, the referent of drastí'seer, one who sees' is an experiencer, not an agent.

It might still be the case that verbs such as 'rain' and 'become' are particularly inappropriate for an agent noun formation. In English, it is true, we can say seer (experiencer) and sufferer (patient), but *becomer, *be-er, and *rainer seem far less acceptable. Yet in Sanskrit there is no such restriction. In fact, agent nouns to both $\sqrt{ }$ vẹs 'rain' and $\sqrt{ } b h \bar{u}$ 'become' exist. várștr- 'rainer', is used to refer to the rain god Parjanya in Vedic Prose (TS 7.5.20.1) $;{ }^{21}$ bhavitr-, meaning 'future, (that which is) coming to be', occurs e.g. in Epic Sanskrit at MBh. 7.172.70, where it is used as a noun in the nom.sg.masc. alongside bhütam 'that which has been, the past' and bhavyam 'that which is now, the present'. Other 'agent' formations are also attested to these roots, for example the 'agentive' adjective formation in -uka-, expressing likelihood: várșuka- 'likely to rain' and bhấvuka- 'likely to become'. There is clearly no restriction against such formations in Sanskrit. Similarly, $\sqrt{ } b h \bar{u}$ can be used in passive-like constructions in Sanskrit, something which is impossible for English become.

The case of vrastata 'it will rain' is worth dwelling on, because it illustrates the dangers of transferring common assumptions from English to ancient languages like Sanskrit. In English, the verb rain is impersonal, taking an expletive subject (it is raining). Many examples of $\sqrt{ } v \underline{v}$ ị in Sanskrit lack a subject, but Sanskrit is a pro-drop language, so it is at least possible that the subject is not expletive, but a permanently available topic, such as 'god'. As noted, the agent noun várștr- 'rainer' is used of Parjanya, the rain god, in Vedic Prose, and the same is true of the 'agentive' adjective vársuka- 'likely to rain':

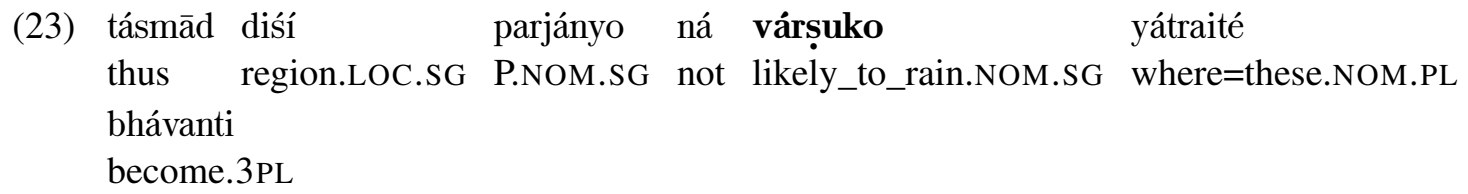

\footnotetext{
${ }^{20}$ This point is made by Fassi Fehri (1993: 258), who labels the equivalent Arabic formation the 'subject nominal'; it is also emphasized by Lowe (2017), who uses the term 'subject(-oriented) noun' in preference to 'agent noun'.

${ }^{21}$ Later Sanskrit also attests varșitr- 'rainer' (Nirukta).
} 
Examples of the finite present varsati '(he/it) rains' with Parjanya as subject abound (e.g. TS 1.6.10.5, TS 2.1.7.3, TS 2.4.1.10, TS 3.4.3.3, TS 5.2.7.2, TS 7.2.7.5, TS 7.5.18.1, to give examples from just one text); the verb can even occur in the causative, with Parjanya as object, e.g. parjányam varșayanti 'they make Parjanya rain' (TS 2.4.10.3). Thus it was at least possible for the verb $\sqrt{ }$ vṛ 'rain' to take an explicit, animate subject in Vedic Sanskrit. The fact that in English the sentence ${ }^{*}$ God is raining is not possible does not mean that verbs of raining and other natural phenomena are necessarily subjectless in other languages.

It is not therefore the case that the formation of the periphrastic future encompasses more roots than the formation of the agent noun, and forms such as 3sg. vraștá 'it will rain' and 3pl. bhavitârah 'they will become' do not provide evidence for a separation of periphrastic future, as a verbal formation, from the agent noun as a non-verbal formation.

Further evidence for the status of the formation might conceivably come from the criterion of 'underexhaustivity' proposed by Spencer (2006: 291): function words in periphrastic constructions may show arbitrary restrictions of form. If the periphrastic future is simply a syntactic collocation of agent noun plus copula, the copula ought in principle to be able to appear in all possible forms, including past tenses and non-indicative moods. The fact that it cannot appear in past tense forms, however, is not surprising, since if we assume the agent noun contributes a FUTURE tense feature in this construction, this would clash with the tense feature of a past tense copula. As for non-indicative moods, there are rare examples of optative copulas in apparent periphrastic perfect constructions. For example, Oberlies (2003b: 239) assigns yoddhā syām at R. 1.19.25, with 1sg. opt. syām, to the periphrastic future. The irrealis sense of the optative, however, means that it is less clear whether the future sense derives from the fact that we are dealing with a periphrastic future construction, or merely derives from the copula, in which case we could be dealing with an ordinary use of the agent noun. In ex. (24), there is little difference between an interpretation in which pratiyoddhā is a form of the future and one in which it is a form of $-t r-$.

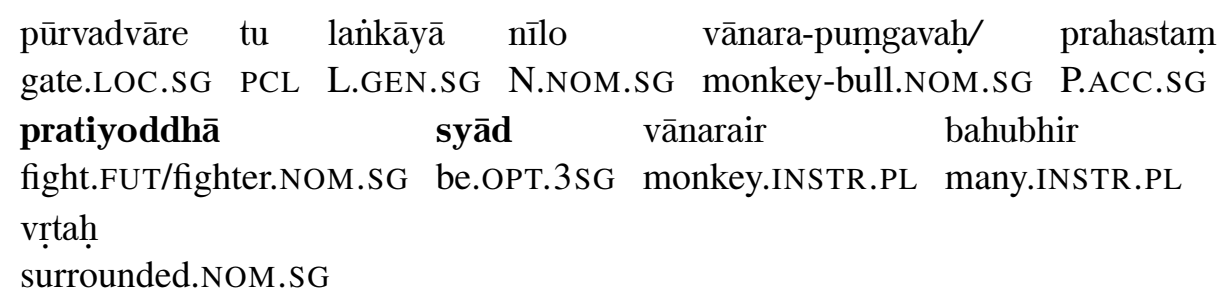

This uncertainty may explain the relative infrequency of periphrastic futures with optative copulas. Thus the copula can appear in all the forms we might expect it to be able to appear in, and there are no arbitrary restrictions which might support the periphrastic status of the construction.

If it were the case that the mediopassive forms of the periphrastic future consisted of two words, one nom.sg.masc. of the agent noun, the other a mediopassive form of the copula, then we might have the converse of 'underexhaustivity': the copula would appear in more forms than would be possible in an ordinary syntactic construction, since mediopassive forms of the copula do not occur independently. ${ }^{22}$ However, as argued above there is no evidence that forms such as kartásvahe are two word sequences, and I treat them as single words. Even as such their existence provides evidence for the periphrastic nature of the construction; this will be discussed further below.

\footnotetext{
${ }^{22}$ This would not be the same as the 'overexhaustivity' criterion of Spencer (2006: 291).
} 
A final point in favour of a morphological analysis of the periphrastic future is the usual lack of gender agreement between agent noun and subject. According to the regular paradigm, the agent noun shows invariant masculine gender, regardless of the gender of the subject. If the periphrastic future were nothing more than a syntactic collocation, the agent noun ought perhaps to appear in the feminine with feminine subjects, and in the neuter with neuter subjects. However, nouns do not regularly make morphological gender distinctions in Sanskrit. Most nouns have one inherent gender, which is used regardless of the gender of the referent. At least in origin, -tr- would have been the same: the neuter forms are rare and largely artificial, easily formed by analogy with adjectival paradigms, while the feminine in $-\overline{1}$ - is originally a derivational category. Some feminine agent nouns reveal their independence of the masculine through their different sense, e.g. dhātr- 'establisher, supporter', but dhātrī- 'nurse'; such independent developments attest to the derivational status of the feminine agent noun. The existence of the feminine $-\overline{1}$ - derivative permitted the agent noun to make gender distinctions, but does not in principle enforce it. Some examples of the periphrastic future in fact show gender 'agreement' with a feminine subject (25). ${ }^{23}$ At the same time, some examples of unambiguous agent nouns do not show gender agreement: in ex. (26) ākhyātuh can only be gen.sg.masc. or nt. of ākhyātr- 'teller', but the addressee of the sentence is female (Mantharā, the servant who turns Kaikeyī against Rāma).

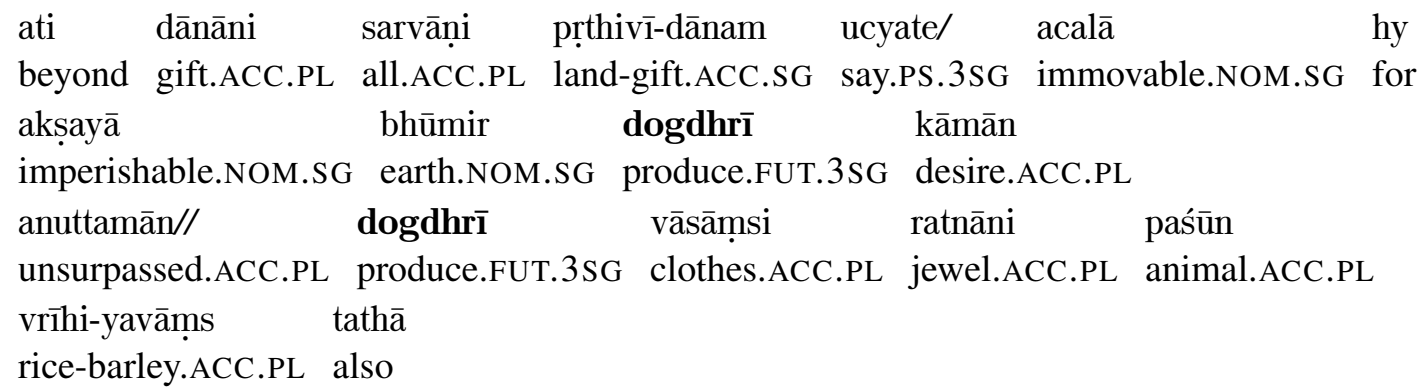

'The gift of land is said to be the best of all gifts. For the earth is immovable, and imperishable; it will produce one's unsurpassed desires, it will produce clothes, jewels, animals, and rice and barley too.' (MBh. 13.61.2-3)

(26)

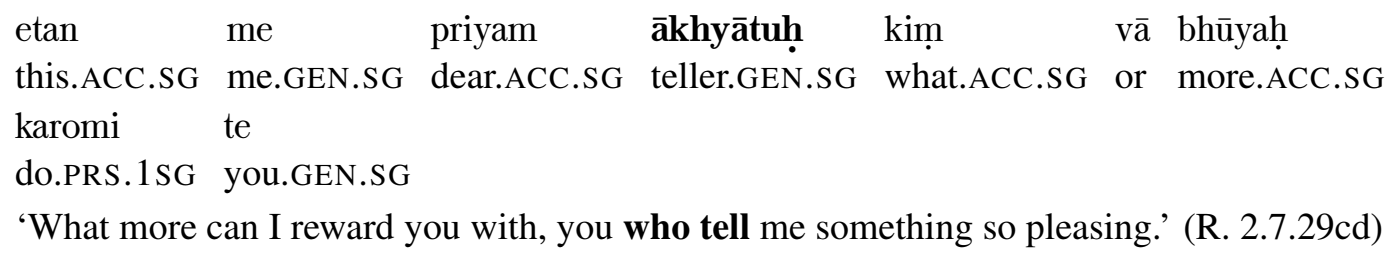

Thus it is necessary to admit that gender 'agreement' with -tr- is not obligatory, and so lack of gender agreement in the periphrastic future does not mean it is necessarily periphrastic. Nevertheless, the agent noun does usually show the expected gender, while the periphrastic future only rarely shows non-masculine forms with non-masculine subjects, so although it is problematic, this may be the best evidence so far for a syntactic distinction between the periphrastic future and a sequence of agent noun plus copula.

In this section I have discussed a number of properties of the periphrastic future which might provide evidence for its status as a true periphrasis and I have argued that none of them stand up to

\footnotetext{
${ }^{23}$ It is possible that $\operatorname{dog} d h r \overline{-}-$ could be analysed as a transitive form of the agent noun, rather than a periphrastic future, but the analysis proposed here is preferable since the agent noun dogdhri-, feminine of dogdhr- 'producer', has an adjectival sense 'productive'.
} 
scrutiny. However, the most important property remains to be discussed. Criterion I of Ackerman \& Stump (2004) was argued above to be the most important criterion for periphrasis: if a multi-word construction fills a slot in the intersecting feature system of a language's grammar, i.e. if it is part of a paradigm, then it is a periphrasis. It is to this question that I turn in the next section.

\section{Paradigmaticity}

There are two respects in which the question of paradigmaticity is relevant to the status of the periphrastic future. The first question is whether the periphrastic future expresses a particular grammatical feature which intersects with other grammatical features in the constitution of the Sanskrit verbal paradigm. The second question relates to the status of the apparently 'synthetic' forms of the periphrastic future, i.e. those forms which are not two words but one: if e.g. 1du. kartásvah is a single word, and if it contrasts in person and number features with 2 pl. kartástha, then a paradigm is implied. That is, the existence of synthetic forms actually serves to prove the periphrastic (paradigmatic) status of the construction, since they cannot be derived from a syntactic sequence of agent noun plus copula. I will treat these two issues in turn.

\subsection{The verbal feature system}

The periphrastic future is not the only, or even the primary, means of expressing future tense in Sanskrit. In the earliest period, before the development of the periphrastic future, the main formation for future tense expression is the subjunctive mood. This falls out of use during the Vedic Prose period, when the periphrastic future is first found. From the earliest period there is also another formation, the finite indicative tense in -sya-, which is often called the 'synthetic future' to distinguish it from the periphrastic future. ${ }^{24}$ The -sya- future is rare in Rgvedic Sanskrit, and may not be a simple future tense formation. As discussed in Lowe (2015), the -sya- future may originate in a desiderative type formation, and its function in Rgvedic Sanskrit may be as much modal as aspectual or marking tense. ${ }^{25}$ By the Vedic Prose period the -sya- future is the main means of referring to future time, and this continues into later Sanskrit.

If both -sya- and periphrastic future formations express exactly the same grammatical features, whether simply FUTURE tense, or some combination of tense/aspect/mood features, then it is questionable whether the periphrastic future counts as a true periphrasis, from a paradigmatic perspective. It would not be an 'obligatory' means of expressing any grammatical feature, and so would not fulfill Bonami \& Samvelian's criterion of 'obligatoriness', and it would be difficult to argue that the formation filled the paradigmatic slot for future tense, given that -sya- is the more frequent formation. Other criteria not withstanding, the periphrastic future could, therefore, be merely a syntactic collocation of agent noun and copula which happened to express the same grammatical feature as the paradigmatic future tense.

The first question, then, is whether there is a semantic or grammatical difference between the -syaand periphrastic futures. The traditional answer to this question is yes. There are two main features usually attributed to the periphrastic future which allegedly distinguish it from the synthetic future (see e.g. Delbrück 1888: 295, and for a recent summary Stump 2012: 118-121 with references). Firstly, there may be a temporal difference: the periphrastic future frequently occurs with temporal adverbs,

\footnotetext{
${ }^{24}$ The synthetic future is morphologically entirely distinct from what I have labelled the 'synthetic' forms of the periphrastic future.

${ }^{25}$ On future expression in the Rgveda, in particular the subjunctive, see also Tichy (2006).
} 
usually referring to a time later than the present day (most commonly śvah or prātar 'tomorrow'). Pānini's Aștādhyāy $\bar{\imath}$ specifies the periphrastic future as referring to future time not on the present day (anadyatane). Thus a difference may be assumed between a non-hodiernal future tense, the periphrastic future, and an unspecified future tense, the synthetic future. Secondly, a greater degree of certainty is often attributed to the periphrastic future, suggesting there may be a difference in modality between the two: the synthetic future is used for standard reference to future events as necessarily uncertain, whereas the periphrastic future expresses the certainty of the speaker that the future event will certainly occur.

As regards the temporal difference, it is true that the periphrastic future frequently occurs with temporal adverbs, often referring to a time following the present day. However, it is also the case that the periphrastic future is frequently used without temporal adverbs, as in all the examples given above, and may in fact refer to a future event taking place on the same day. In ex. (27), the periphrastic future even occurs with the adverb adya 'today'. ${ }^{26}$

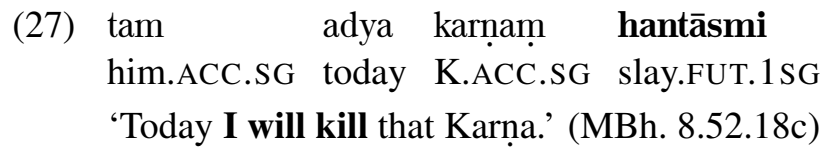

If the periphrastic future were merely a syntactic collocation of agent noun and copula, which could in context refer to a future event but need not necessarily (since the agent noun does not always have a future sense), then the frequent occurrence of the construction with temporal adverbs, in particular those referring to a non-hodiernal future, would be entirely expected: a temporal adverb with the sense 'tomorrow', for example, would disambiguate the temporal reference of the construction in cases where both future and present interpretations were possible. This would not mean that such adverbs were always necessary, but that they were used only when the speaker felt the need to rule out the present interpretation. On the other hand, a temporal adverb like 'today' could not be used to disambiguate between present and hodiernal future, so it would likely be less frequent, though still possible. Thus the tendency for the periphrastic future to occur with temporal adverbs, and to express non-hodiernal future tense, can be fully explained without assuming the formation is a paradigmatic non-hodiernal future.

The claim that the periphrastic future expresses a more certain future event than the synthetic future likewise does not hold consistently. Oberlies (2003b: 158) notes that there is very often no semantic difference between the periphrastic future and the synthetic future. In ex. (28), a periphrastic future is coordinated with a synthetic future from the same root, and the two seem to be equivalent in terms of their temporal reference. Ex. (29) shows an almost identical verse from later in the same section as ex. (28), but here we find two periphrastic futures coordinated, again suggesting (in comparison with ex. 28) the temporal equivalence of periphrastic and synthetic futures. ${ }^{27}$

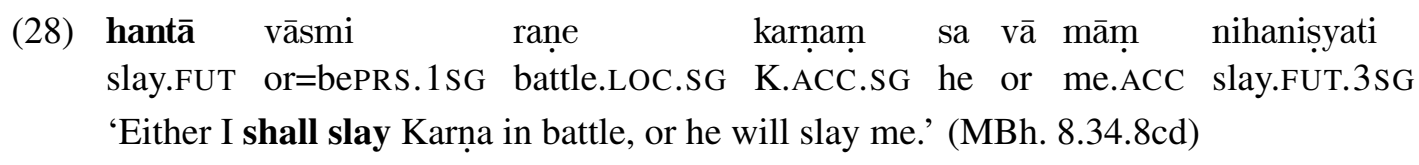

\footnotetext{
${ }^{26}$ This example is given by Stump (2012: 119) as MBh. 8.74.29; in most cases, Stump takes verse numbers directly from Speyer (1886) or Whitney (1896), who were writing before the publication of critical editions of the epics. All such citations here are from the online critical editions by BORI (1999) and Smith (2014), based on Sukthankar et al. (1933-1966) and Bhatt et al. (1960-1975) respectively.

${ }^{27}$ Hara (1987) finds a similar equivalence between periphrastic and synthetic futures in the context of oaths in the Mahābhārata.
} 


$$
\begin{aligned}
& \text { hantāham arjunam sạ̣khye māṃ vā hantā dhanamijayạ̣ } \\
& \text { slay.FUT=I A.ACC.SG battle.LOC.SG me.ACC or slay.FUT(3SG) Dh.NOM.SG } \\
& \text { 'Either I shall slay Arjuna in battle, or Dhanamjaya will slay me.' (MBh. 8.34.26cd) }
\end{aligned}
$$

It is by no means clear, then, that the periphrastic future expresses different grammatical features from the synthetic future. In many, if not most, cases, they appear equivalent. For the sake of argument, however, let us assume that there is a grammatical difference between the two future expressions. Such a difference is not enough to demonstrate that the construction is a true periphrasis in the paradigmatic sense, unless it can also be demonstrated that the grammatical feature combination specific to the periphrastic future is a part of the Sanskrit verbal paradigm, in the sense of being implied by the logically possible set of combinations of features which are grammatically expressed in Sanskrit.

The alleged modal difference between the futures is not a good candidate for a paradigmatic distinction. The Sanskrit verb system distinguishes a number of moods, but there is no paradigmatic modal contrast which is systematically found across different tense categories. In post-Vedic Sanskrit, modal categories are all but entirely restricted to present tense stems; finite past and future tense stems do not regularly distinguish moods, being restricted to the indicative. Even in Vedic Sanskrit, where past tense modal forms are found, they appear obsolescent and clear systematic oppositions between modal formations to the different tenses are not found. ${ }^{28}$ As shown above, the periphrastic future is not incompatible with an optative auxiliary, showing that any modal sense specific to the periphrastic future does not stand in paradigmatic opposition to the non-indicative moods of the Sanskrit verbal system. While it is possible, therefore, that there is some kind of modal difference between synthetic and periphrastic future, there is no reason to assume that such a difference is part of the paradigmatic oppositions that constitute the Sanskrit verbal paradigm.

When it comes to the difference between hodiernal and non-hodiernal future time reference, a grammatical distinction appears less unlikely. For Classical Sanskrit, Pānini uses the hodiernal/nonhodiernal distinction for both past and future tenses. While the inherited aorist tense is specified for general past time, much like the synthetic future is specified for general future time, the inherited 'imperfect' tense is specified for non-hodiernal past time. Thus two clearly distinct, and clearly inflectional, past tense categories mark the same remoteness distinction which is marked by the contrast between synthetic and periphrastic future, according to Pạnini. There is also a third past tense, the perfect, which contrasts with the aorist and imperfect in terms of evidentiality: it is specified by Pannini for use when the event was not witnessed by the speaker. As discussed by Lowe (2015: 340), in Pāninin's Asta $\bar{a} d h y \bar{a} y \bar{\imath}$ the parallelism between the aorist/imperfect and synthetic future/periphrastic future tenses goes beyond the simple hodiernal/non-hodiernal distinction; there is a further blocking relation, by which the imperfect and periphrastic future are blocked from non-hodiernal use in the context of temporal proximity or imperfectivity/iteration. It is therefore plausible that in Pāninian Sanskrit the remoteness distinction between hodiernal and non-hodiernal tense is a paradigmatic distinction, intersecting with the tense feature, and implying a future non-hodiernal tense parallel to the non-hodiernal past tense. ${ }^{29}$

The question is how widely across the range of Sanskrit literature the remoteness distinctions specified by Pạnini can be assumed to apply. It has already been shown that it does not apply consistently in the case of the future. In the case of the past tenses, the situation is different at different chronological periods. In Rgvedic Sanskrit and earlier Vedic Prose, the past tenses are not primarily distinguished by remoteness or evidentiality. Authors such as Kiparsky (2002), Dahl (2010) and Lowe (2015) propose slightly different accounts of the grammatical differences between the three past tenses

\footnotetext{
${ }^{28}$ This is clearly shown by Jamison (2009, forthcoming a,b).

${ }^{29}$ In the present, of course, the hodiernal/non-hodiernal distinction is not possible.
} 
in early Vedic, but for all the primary differences are tense/aspect distinctions. Crucially this includes the period where the periphrastic future first developed. In the epics and other 'non-standard' Classical Sanskrit, the three past tenses are all used, but there is usually no clear difference between them (Oberlies 2003b: 152-155), suggesting that the three tenses have survived distinct in form, but functionally they are mere formal (often metrical) alternatives. In Classical Sanskrit, the inherited past tenses are rare, and tend to be concentrated in particular texts, where their use is primarily stylistic. The usual means of expressing past tense in Classical Sanskrit is by means of the 'past passive participle', which is all but grammaticalized as a finite past tense. Thus in post-Vedic Sanskrit, the evidence suggests that there was only really a single past tense, in paradigmatic terms, but that the three inherited finite past tenses remained morphological possibilities for expressing past tense alongside the past passive participle construction, the formation that replaced them. Their survival in the epics is clearly an inheritance from the earlier stages of the Epic tradition, while their survival in Classical Sanskrit is due solely to their prescription in Pạnini's Aṣtāadhyāỹu.

Thus, besides Pānini's grammar and the Vedic dialect on which it was based, there is little evidence for a remoteness/evidentiality distinction in the Sanskrit verbal system. Moreover, to the extent that evidence for the distinction does exist, this evidence relates exclusively to the past tenses: outside Pāninin's grammar and Pāṇinian Sanskrit there is essentially no evidence for a remoteness/evidentiality distinction between the synthetic and periphrastic future tenses.

In conclusion, then, it is possible but not necessary that there was a genuine grammatical distinction between hodiernal and non-hodiernal tense in the Sanskrit dialect described by Pạnini, but through most of the history of Sanskrit this distinction is not in evidence. Where this distinction is in evidence, there is paradigmatic support for the periphrastic status of the periphrastic future, but where it is not, there is not.

An alternative possibility is advanced by Tichy (1992), who argues that the development of the periphrastic future was dependent on a gap opening up in the verbal paradigm, due to the narrowing of use of the subjunctive in main clauses. Tichy argues that the periphrastic future construction was integrated into the verbal paradigm to provide an indicative counterpart to the 'future imperative' in -tât, contrasting with the synthetic future, which functioned as indicative counterpart to the present imperative. This argument is certainly attractive, although the rarity of the future imperative makes it uncertain itself as a part of the Sanskrit verbal paradigm. But even granted that, it is important to note that the argument works only for the early Vedic Prose period (which Tichy focuses on). The future sense of the future imperative has been established for early Vedic Prose (Delbrück 1878: 2-6), but in later Sanskrit the construction is extremely rare, and does not show specifically future sense. ${ }^{30}$ As with the hodiernal/non-hodiernal distinction, then, there may be some support for a paradigmatic opposition which might support the periphrastic status of the periphrastic future, but only at one specific period of Sanskrit.

\section{2 'Synthetic' forms}

The second type of paradigmatic evidence provides the only incontestable evidence for the periphrastic status of the periphrastic future, yet as we will see even this is problematic at most periods.

The morphological status of the $1 / 2 . \mathrm{du} / \mathrm{pl}$. forms of the active periphrastic future paradigm, and of all 1st/2nd. person forms of the middle, was discussed above. The main question was whether the forms concerned, e.g. 1du. kartấsvạ 'we two will make', are single words or sequences of nom.sg.masc. agent noun plus copular. Stump (2012) is one of the few authors who assume that all forms involve

\footnotetext{
${ }^{30}$ Pānini specifies the future imperative for use only in benedictions (Așt. 7.1.35), with no more specifically future sense than the standard 'present' imperative.
} 
two words, so e.g. kartá svah. As noted above, there is no positive evidence for such an analysis, even with the active forms, where the two parts would at least be real words. In the case of the middle, there is actually positive evidence against the two word analysis, since the resulting copula forms, e.g. 1sg. * he, do not exist as independent words.

I take the single word status of sequences like kartásvạ̣ to require no further argument. However, whether single words or two words, the sequences in question are problematic for the claim that the periphrastic future is nothing but a syntactic collocation of agent noun and copula. If the forms are two word sequences, then they are problematic for a purely syntactic analysis on two grounds: the singular form of the agent noun even in the dual and plural, and the use of middle forms of the copula, forms which do not exist as independent words. These problems might just about be surmountable, but they would require special syntactic rules and morphological forms not used outside the construction, which would imply an at least partially morphological status of the construction.

If the forms in question are single morphological words, on the other hand, then a periphrastic analysis of the formation is unavoidable. A word such as kartásvạ could only be a finite verb form. There would therefore be a verbal paradigm expressing future tense, with most person/number slots (all but $1 / 2 . \mathrm{sg}$.) filled by single words. The $1 \mathrm{sg}$. and $2 \mathrm{sg}$. forms are most naturally analysed as sequences of agent noun plus copula (due to the possibility of separation, or absence of the copula), so would constitute periphrastic expressions of the (e.g. non-hodiernal) future paradigm. In essence, if single word forms of the periphrastic future exist, then a paradigm must exist, and therefore the formation must be part of the inflectional system of the Sanskrit verbal system.

Given the existence of forms like kartásvah, then, it would appear the case is closed: the periphrastic future is indeed a part of the Sanskrit verbal paradigm, and at least two person number combinations (1sg. and 2sg. active) are realized periphrastically. However, a detailed search of a considerable volume of Sanskrit literature reveals a surprising fact: the crucial 'synthetic' forms of the periphrastic future are unattested throughout a considerable period in Sanskrit history. ${ }^{31}$ The distribution of 'synthetic' forms across the history of Sanskrit suggests that it was the innovation of a specific sociolect which was not continued in later mainstream Sanskrit but which, through its acceptance by Pānini, did survive as a learned feature of later Classical Sanskrit, long after Sanskrit ceased to exist as a living language.

As mentioned above it is usually assumed that in the earliest Vedic text, the Rgveda, there is no sign of the periphrastic future. It is very clearly present in the oldest Vedic Prose texts, however. Most importantly, in early Vedic Prose we do find middle and 1/2.du/pl. active forms of the periphrastic future, i.e. the crucial 'synthetic' forms. Ex. (30) shows a 1pl. active form of the periphrastic future from the Aitareya Brāhamana; ex. (31) shows a 2sg. mediopassive form from the Śatapatha Brāhmana; ex. (32) shows a 1sg. mediopassive form from the Taittirīya Āranyaka.

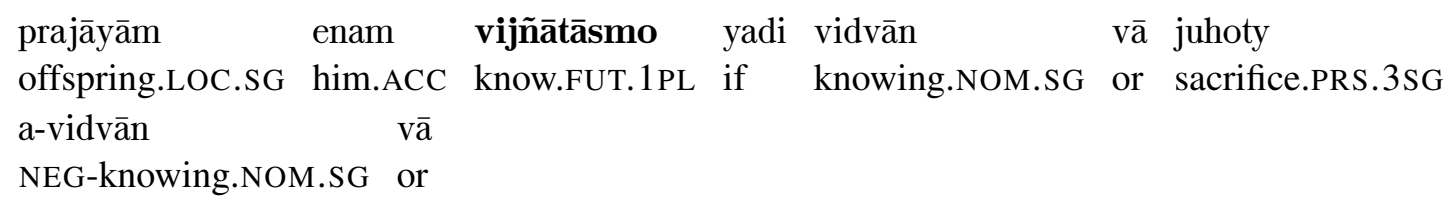

'In his offspring we will know him, whether he sacrifices with knowledge or without knowledge.' (AB 5.30.15)

(31) tán ma ékāṃ rătrim ánte sayitáse

then me.GEN one.ACC night.ACC.SG near lie.FUT.2SG.MED

\footnotetext{
${ }^{31}$ The data presented in the rest of this section comes primarily from electronic searches of a wide range of Sanskrit texts, as specified below, all accessed, except where indicated, via the Göttingen Register of Electronic Texts in Indian Languages (GRETIL) at http://gretil.sub.uni-goettingen.de/; texts were last accessed on 20 July 2016.
} 
'Then you will lie near me for one night.' (ŚB 11.5.1.11)

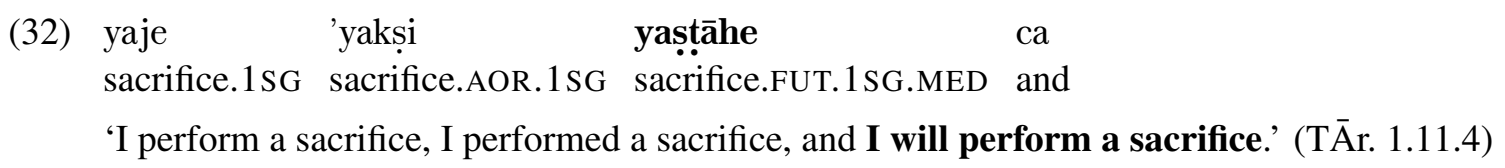

In the early Vedic Prose language, then, the periphrastic future uncontroversially exists: we must reckon with a full active and middle paradigm integrated into the verbal system. Whether the paradigm is truly periphrastic is another question: I am aware of no examples from early Vedic Prose in which the copula is separated from the 'agent noun' component, i.e. examples which would prove that the $1 / 2 \mathrm{sg}$. forms of the paradigm, at least, were formed from two-word periphrases. That is, it is possible that early Vedic in fact attests a fully synthetic paradigm, just as we find specified in Pānini's Aștādhyāy (cf. fn. 12).

It is worth noting also that there are a few irregular forms of the paradigm which suggest it was only recently grammaticalized and still in flux. So, the earliest example of a 1sg. mediopassive (ex. 33) does not show the later 'regular' ending -āhe, but an ending -āse, which is in some sense the expected 1sg. med. form. There is also at least one form with 'irregular' accent: yástāsamahe (ex. 34), for expected yaștásmahe. This form suggests there may have been some fluctuation in whether the periphrastic future was treated as formed to the agent noun in -tṛ- or the agent noun in -tŕ-.

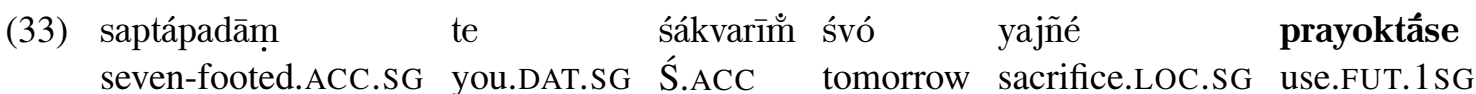

'I will use seven-footed Śakvarī for you at the sacrifice tomorrow.' (TS 2.6.2.3)

(34) tám ālábhyópāvasan prātár yásțāsmaha íti

him.ACC take.ABS=wait.IMF.3PL tomorrow sacrifice.FUT.MED.1PL QUOT

'Having taken him (Prajāpati in form of a beast) they waited, thinking 'we will make sacrifice tomorrow'.' (TB 3.9.22.1)

The 'synthetic' forms of the paradigm, which alone prove the existence of the paradigm as distinct from a collocation of agent noun plus copula, are rare. In the Taittirīya Samhitā, one of the very oldest Vedic Prose texts, there is only the single $1 \mathrm{sg}$. form given in ex. (33), beside two $2 \mathrm{sg}$. actives in -âsi, and one 3pl. (TS 7.3.1.3). In the Taittirìya Brāhmana there is again only a single 'synthetic' form, that given in ex. (34); all other forms are 3sg. The Śatapatha Brāhmana likewise attests only a single 'synthetic' form (ex. 31). In the Kausītaki Brähmana there is a single 1pl. active, and there are two 1pl. actives in the Aitareya Brāhmana. There are none at all in the relatively early Pañcavimśa Brāhmana, and none in the late Gopatha Brähmana. ${ }^{32}$ Nevertheless, despite the rarity of such forms, it remains the case that early Vedic Prose unambiguously attests a 'periphrastic future' paradigm.

In the later Vedic Prose period, the crucial 'synthetic' forms of the paradigm are at best extremely rare, and perhaps unattested. I am aware of no forms from the later Brāhmanas; there is at least one form in the Taittirìya Âranyaka (ex. 32), but the only Āranyaka available in searchable form, the Śänkhāyana Āranyaka (Kümmel 2015), contains no periphrastic future forms which are not $3 \mathrm{sg}$. Likewise the twelve Upanișads available on GRETIL contain no periphrastic future forms which are not 3sg. Together, the Śánkhāyana Āranyaka and Upaniṣads on GRETIL amount to around 62,000

\footnotetext{
${ }^{32}$ Stump (2012: 120) cites a form prāptāsmah, apparently 1pl. periphrastic future, at Gopatha Brāhmana 1.1.28, but the form is better corrected to prāptāh smạ, as in the electronic texts (e.g. Griffiths 2005-2006), since the context does not support a future sense.
} 
words. In early Post-Vedic, too, there are no 'synthetic' forms, and very few periphrastic futures altogether. An electronic search of all the Vedānga texts available on GRETIL, which together amount to 290,000 words, finds only a couple of $1 / 2 \mathrm{sg}$. forms, beside $3 \mathrm{sgs}$.

It may well be, of course, that periphrastic futures are better attested in other late and post-Vedic texts which are not currently available in electronic form. The likelihood of finding any significant number of 'synthetic' periphrastic future forms seems low, but cannot be excluded. At the very least, it appears to be the case that the periphrastic future was a marginal construction in late Vedic and Vedānga texts. It cannot be ruled out that it was a rare but nevertheless genuine part of the language, and that 'synthetic' $1 / 2$.du/pl. and middle forms were grammatical, meaning that the construction must be considered a part of the verbal paradigm. However, it also cannot be taken for granted.

While the lack of data from late Vedic and Vedānga texts cannot be considered definitive, the data from the Sanskrit epics is much more telling. The two great Sanskrit epics provide the most important body of post-Vedic, but non-Classical, Sanskrit, and chronologically overlap with the very late Vedic Prose period and the post-Vedic period. The Mahābhärata runs to roughly one million words, while the Rāmāyana runs to somewhere over 200,000 words. It has not previously been recognized that in this relatively large corpus there is not a single 'synthetic' form of the periphrastic future. 1sg. and $2 \mathrm{sg}$. active forms are not uncommon, and active 3rd person forms are common. For example, according to Brockington $(1967,1969)$, the periphrastic future is a late feature in the Rāmāyana, but there are 60 instances in total: 15 1sg., 13 2sg., $303 \mathrm{sg}$., and two 3pl forms. ${ }^{33}$ In the Mahābhārata there are more than $1001 \mathrm{sg}$. forms.

The rarity of mediopassive forms of the periphrastic future outside early Vedic Prose has been widely recognized, so let us consider only the active 'synthetic' forms, i.e. the $1 / 2 . \mathrm{du} / \mathrm{pl}$. active forms. ${ }^{34}$

Of course, we would not expect such person/number combinations to be particularly common, particularly the duals. Considering the figures for the synthetic future paradigm in -sya-, in the Mahäbhärata there are more than 1700 1sg., 600 2sg., 1300 3sg., and 300 3pl. forms, but only 163 1pl., 14 1du., 88 2pl. and $62 \mathrm{du}$. forms. That is, for - sya-, 1/2.du/pl. forms make up only $6.5 \%$ of attested forms. But despite this low proportion, if we assume it is equally applicable to the periphrastic future we might still expect around twenty $1 / 2$.du/pl. forms to occur in the epics.

The complete absence of 1/2.du/pl. forms like kartásmah from the epics is therefore unexpected, but if this were all it might still be possible to argue that this is simply an accidental gap. Crucially, however, 1/2.du/pl. periphrastic future forms are attested in the Mahābhärata, if one includes unambiguously analytic formations such as kartārau svạ 'we two will make'. The Mahābhārata attests

\footnotetext{
${ }^{33}$ These figures are as counted by Brockington, partly in Brockington (1967) and partly in unpublished lists generously made available to the author. Of the $281 / 2 \mathrm{sg}$. forms in the Rāmāyana, 13 are unambiguously 'analytic', in the sense that they are not the 'regular' forms involving agent noun directly followed by copula. We find copula preceding the agent noun, personal pronoun indicating person with no copula, and clitics separating agent noun from following copula.

${ }^{34}$ There are no mediopassive periphrastic future forms in the epics. According to Speyer (1896: 258), distinctive (i.e. $1 / 2$ person) mediopassive forms are not found after the Vedic Prose period, but this is not accurate, as discussed below. Speyer (1886: 258) gives two examples of 3rd person forms with mediopassive sense, one from the Classical Kirātārjunīya (3.22), another from the Rammayana. If the latter example were genuine, it would be problematic for the argument made in this section, since one would have to reckon with a voice distinction, and therefore a paradigmatic voice opposition, for the periphrastic future in the Epic period. However, the form in question, dharsita 'attacked', is clearly to be interpreted as a past participle (it agrees with a feminine subject). The Kirātārjunīya example is also problematic: Speyer, followed by Stump (2012: 118), reads the forms in question as unmūlayitārah 'they will be eradicated', based on the transitive stem unmūlaya'eradicate'; however, the text by Godabole \& Paraba (1885: 49) reads unmūlitārah 'will be eradicated', which is not passive but intransitive, based on the class VI stem unmūlati 'is eradicated'. The electronic text by Isaacson (n.d.) gives the form as unmīlitārah 'will appear', again intransitive rather than passive. It is therefore far from certain that this is a genuine example of a 3rd person form used passively. The only sure examples I have found are from the Bhattikâvya, mentioned below, where they are clearly artificial.
} 
fourteen such sequences, not far off the expected the number of 1/2.du/pl. forms. There are two $1 \mathrm{du}$., nine $1 \mathrm{pl}$., and three $2 \mathrm{pl}$. forms. ${ }^{35}$ Seven of the fourteen examples involve a copula, while seven have a personal pronoun indicating person and no explicit copula. Eight order the copula/pronoun after the agent noun element, while six show the copula/pronoun preceding the agent noun element. Importantly, in all instances the agent noun shows number agreement: plural with a plural copula/pronoun, dual with a dual copula/pronoun. This is exactly what we would expect if the periphrastic future were a syntactic collocation involving a predicated agent noun.

The absence of 'synthetic' 1/2.du/pl. periphrastic future forms from the epics is therefore no accident: they were not part of the Epic Sanskrit grammar. Instead, a syntactic collocation of predicated agent noun, with subject pronoun or copula indicating person, was used. As argued above, the 'synthetic' periphrastic future forms are the only forms which prove the paradigmatic status of the periphrastic future. Thus we may reasonably conclude that the periphrastic future was not a part of the verbal paradigm in Epic Sanskrit, but was a purely syntactic construction. Once we acknowledge this, the absence of mediopassive forms is no longer remarkable: mediopassive forms are only possible if the construction is paradigmatized. While this appears to have been the case in early Vedic Prose, it was not the case in Epic Sanskrit.

This remarkable difference between the grammars of Epic Sanskrit and early Vedic Prose Sanskrit has never been recognized, and many discussions of the periphrastic future, including that by Stump (2012), provide a false view of the construction by treating the Epic and Vedic Prose data together. The question is now whether other varieties of Sanskrit correspond more closely to early Vedic Prose or Epic Sanskrit. As discussed above, late Vedic Prose and the Vedāngas are unclear, since the periphrastic future seems all but absent. This seems more likely to correspond to a grammar in which there is no paradigmatic periphrastic future than one in which there is, but the question must remain open.

The Purānas are a voluminous collection of texts whose origins lie in the latter half of the first millenium B.C., but which were composed in the form in which we have them over a number of centuries after about 400 A.D. The Purānas are known to be consciously imitative of the epics, and indeed the evidence of the Purānas for the status of the periphrastic future is almost identical to that of the epics. The Purānas available on GRETIL provide an electronic corpus of around two million words. ${ }^{36}$ In general, the periphrastic future is rarer than in the epics. There is one brief passage in the Agni Purāna (AP 357.24-25) which contains six 'synthetic' forms of the periphrastic future, including three mediopassives, but the passage in question is explicitly grammatical in scope, and cites the relevant forms merely as examples of correct tense formation. The use of Pānini's code label for the periphrastic future, lut, shows that the author was doing nothing more than reproducing Pāninian forms.

Discounting these forms, there are no 'synthetic' 1/2.du/pl. or mediopassive forms in the Purānas. There are however five $1 / 2$.du/pl. active analytic forms, i.e. forms with number agreement on the agent noun and separate copula/pronoun indicating person. ${ }^{37}$ Thus the Purānas show exactly the same as

\footnotetext{
${ }^{35}$ The forms are: kartārau sva(ḥ) (MBh. 1.215.19), dātārau svạ̣ (MBh. 3.194.20), kartāraḥ sma(ḥ) (MBh. 1.53.21), yūyam... āgantārạ (MBh. 1.189.26), kartārah sma vayam (MBh. 7.16.14), yūyam...ucchettārặ (MBh. 16.2.9), stha patitārạ̣ (MBh. 1.41.8), gantāro vayam (MBh. 1.88.10), vijetāro vayam (MBh. 13.142.6), aham...(+PN+PN)...kartārạ̣ (MBh. 14.71.3), āgantārạ̣... sma(ḥ) (MBh. 3.242.15), vayạ̣ kṣamitārạ̣ (MBh. 7.169.53), draștāạ̣ sma(ḥ) (MBh. 3.238.3), vayam...drastārah (MBh. 3.84.15). On the 'irregular' forms of the 1pl. and 1du. copulas, sma and sva respectively, see Oberlies (2003a: 170-172, 206-207): this is a common irregularity in the epics, its origin may be metrical convenience.

${ }^{36}$ In addition, the Harivaṃśa, which is sometimes classified as a Purāna, runs to 170,000 words but contains no 'synthetic' forms.

${ }^{37}$ These are: gantārạ̣ stha (BndP. 3.4.42), yūyam pratiseddhārạ̣ (BhP. 6.1.32), yūyam bhavitārạ̣ (BrP. 158.19), gantāro
} 
the epics: there is no evidence that the periphrastic future was a paradigmatic formation in Purānic Sanskrit, rather than a syntactic collocation involving the agent noun in -tr-. Imitative of the epics though the Purānas are, this is remarkable given that the Purānas were composed considerably later than the epics, at a period where standardized Pāninian Sanskrit was well known. The Agni Purāna passage discussed above shows that the periphrastic future was known to the authors of the Purannas as a paradigmatic formation in Pāninian Sanskrit, but it was not used as such by the authors of the Purānas themselves.

In Classical Sanskrit texts, 'synthetic' forms are found, but this is not surprising since it is to be expected that Classical authors would make use of the full range of the Sanskrit language made available to them by Pạnini. Forms are still rare, and usually late. The Sanskrit texts listed on GRETIL as Vaiśnava or Śaiva religious texts come to about 1.1 million words. There is only a single 'synthetic' form (vs. about 6 1sgs.), a middle, îkṣitāsmahe 'we will see' (the root is medium tantum), in a 14th century text. The texts listed under the headings of Kāyva, Drama, Narrative and Subhāṣita texts (under the main heading of Poetry) on GRETIL run to over 1 million words. These include a number of the most famous works of Sanskrit literature, in particular several works by Kālidāsa. Here we find fourteen 'synthetic' forms. However, eleven of these occur in the final section of Bhattii's Bhattikāvya; this section is part of the Tinanta Khanda of the Bhattika $v y a$, which is devoted to illustrating the Panninian finite verb categories, the last of which is the periphrastic future. Thus these eleven forms, and indeed all the examples of the future in this section, can only be taken as exemplars of Pāninian grammar. $^{38}$

The Bhattikāvya is dated to the 7th century A.D. The remaining three forms from the Poetic corpus are later: two are from Buddhasvāmin's Bṛhatkathāślokasamgraha (BKS 10.273, 21.67), dated to the 9th cent., the other is in Jivva Gosvāmin's Gopālacampü (fllg. GC 1.21.63), from the 16th century. All three forms are mediopassives. Clearly such occasional forms in such late texts may be nothing more than sporadic Pāninisms. At the same time, there are at least two analytic 1/2.du/pl. forms: one occurs in Kșemendra's Bhāratamañjarī (BhM 19.174), a retelling of the Mahābhārata and likely therefore imitating epic phraseology; the other occurs in the play Svapnavāsavadatta, attributed to Bhāsa, of uncertain date.

In general, then, mediopassive and 1/2.du/pl. active forms of the periphrastic future are avoided in later Sanskrit, and the few occurrences identified in the corpora analysed for this paper tell us relatively little. The rarity of such forms may attest to an uncertainty on the part of Classical Sanskrit authors, despite their certain familiarity with the formation as prescribed by Pạnini. Overall, there is no clear evidence to refute the claim that the periphrastic future as a (periphrastic or synthetic) part of the verbal paradigm was something of an artificiality in Classical Sanskrit, deriving entirely from its specification by Pānini (based on the early Vedic Prose language) and not reflecting the more natural, colloquial use of the language as attested in the Sanskrit epics and inherited by the Classical tradition.

vayam (MatsP. 42.10), śāsitāro vayam (ViP. 1.17.50)

${ }^{38}$ The artificiality of the language in this part of the Bhattikāvya is clear from the heavy use of the passive construction, which is otherwise almost never found with the periphrastic future. For example, at BhK 22.6 'you(sg.) will see' is the 'expected' draștāsi, but at BhK 22.4, BhK 22.7 and BhK 22.10 the same sense is rendered by 3rd person forms interpreted passively, respectively darśitāras tvayā lit. '(pl) will be seen by you(sg)', tvayā saṃdarśitārau lit. '(du) will be seen by you(sg)' and bhavatā darśitā... draștāraś ca '(sg) and (pl) will be seen by you(sg.hon)'. Even the periphrastic future of gam 'go' is used passively: gantāyodhyā tvayā lit. 'Ayodhyā will be gone to by you'. 


\section{A diachronic aCcount}

It must therefore be acknowledged that the periphrastic future has a rather uncertain status for the majority of the history of Sanskrit, and crucially its status is not uniform following its appearance in the Vedic Prose period. In early Vedic Prose the periphrastic future is undoubtedly a paradigmatic part of the Sanskrit verbal paradigm. ${ }^{39}$ This may be best understood, following Tichy (1992), in terms of the ongoing obsolescence of the subjunctive and the paradigmatic opposition between present and future imperative in Vedic Prose.

But there is little or no evidence that the early Vedic Prose paradigmatization of the periphrastic future was continued in later Vedic and post-Vedic, and in Epic Sanskrit and the Purānas the periphrastic future is indistinguishable from a sequence of agent noun plus copula. This suggests that the paradigmatization of the periphrastic future was a development peculiar to the early Vedic Prose dialect, not shared with the more colloquial contemporary dialects which fed into the later language. The early Vedic Prose paradigmatization was adopted into Pānini's grammar, however, from where it became available for use in the Classical language, although even there unambiguously paradigmatized forms are rare.

According to standard accounts, the periphrastic future does not exist in the Rgveda, being unambiguously attested only from the early Vedic Prose period. ${ }^{40}$ However, once we acknowledge that the periphrastic future as a paradigmatic tense formation was an innovation peculiar to the early Vedic Prose language, and that for the most part in the history of Sanskrit the 'periphrastic future' was merely a syntactic construction involving a form of the agent noun in -tr- with (usually) future sense, it is worth considering again whether there are any traces of this syntactic construction in the earliest period. As mentioned above, Jamison \& Brereton (2014) assign a future sense to some instances of the agent noun in the Rgveda, but such a semantic development is not necessarily dependent on any syntactic development which could be associated with the later periphrastic future. That is, the issue is not whether there is any semantic development towards the periphrastic future in the Rgveda, but whether there is any syntactic development in that direction.

As discussed above there are two accentual variants of the -tr- agent noun in the Rgveda, and there are strong tendencies in their object government: -tr- usually governs accusative objects, while -tŕusually governs its logical object in the genitive. On grounds of accent, it is likely that the periphrastic future is based on -tŕ-, not -tr-, which is unexpected given the regular genitive government of the former in the Rgveda. However, even in the Rgveda there are up to thirteen examples of -trí- governing accusative objects. Most of these cannot be connected with the later periphrastic future, but are directly related to the transitivity of -tr-: Kiparsky (2016) shows clearly that there are morphological restrictions on the formation of nouns in -tr-, and that -tŕ- could serve as a proxy for -tṛ- where necessary. So, -trcan only attach to a bare root in the Rgveda; prefixed forms such as nícetr- 'observer' were formed by prefixation of the resulting noun. That is, with -tr- e.g. [ní- [ce -tr] ]-] is possible but [[ní- ce] -tr] - is not. In place of the latter, a -tŕ- formation was used: [[ni- ce] -tŕ ]-. This accounts for most of the stems in -tŕ- which are found governing accusative objects in the Rgveda: nicetr'- 'observer' to ní- $\sqrt{ }$ ci, pranetr''leader forth' to prá- $\sqrt{ } n \bar{n}$, upaśrotŕ- 'hearer' to úpa- $\sqrt{ }$ śru, the possibly transitive apavaktí- 'exorciser' to ápa- $\sqrt{ }$ vac, prayantị́- 'provider' to prá- $\sqrt{ }$ yam, prahantị́- 'smasher' to prá- $\sqrt{ }$ han, apavartị́- 'opener'

\footnotetext{
${ }^{39}$ Though it is not necessarily a periphrasis, as noted above, since there is no evidence that any forms of the paradigm necessarily consisted of two words in early Vedic Prose.

${ }^{40}$ The existence of the periphrastic future in the Atharvaveda is uncertain. There are no clear examples in the Śaunaka recension, but Lubotsky $(2002: 68,139)$ finds two examples in the Paippalāda recension (AVP 5.12.4a and AVP 5.31.5d); both are intransitive and $3 \mathrm{sg}$., and so could arguably be forms of the agent noun.
} 
to ápa- $\sqrt{ } v r$, abhisvartị́- 'sounder' to abhí- $\sqrt{ }$ svar. ${ }^{41}$

However, there remain two transitive stems in -tṛ́-: yantŕ-, transitive in two instances (exx. 35 and 36), and avitŕ-, transitive once (ex. 37).

(35)
soma tanūkŕdbhyo
dvésobhyo
'nyákrtebhya
you.NOM.SG S.VOC self-made.ABL.PL hostility.ABL.PL
urú yantási
other-made.ABL.PL
várūtham
wide.ACC.SG provider.NOM.SG=be.2SG/provide.FUT.2SG protection.ACC.SG

'You, Soma, provide wide protection from hostility, whether of our own making or of others.'

(RV 8.79.3)

(36)
dádhir
yó
dhăyi
sá te
váyāṃsi
establishing.NOM.SG who.NOM.SG
establish.PS.AOR.3SG he you.DAT power.ACC.PL
yantá vásūni vidhaté tanū-páh
provider.NOM.SG wealth.ACC.PL worshipper.DAT.SG body-protector.NOM.SG

'He establishes powers for you, who is established, he, protector of bodies, provides wealth to the worshipper.' (RV 10.46.1cd)

(37) inó

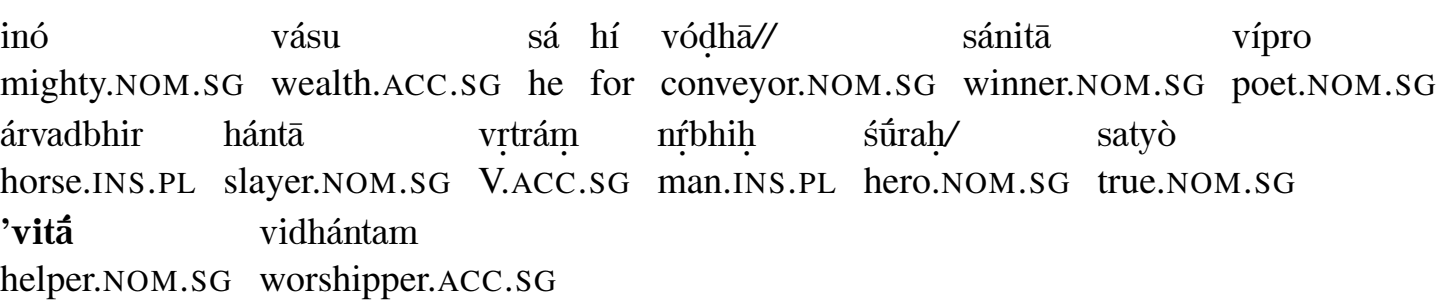

'For he is the mighty conveyor of wealth; (he is) the winner, poet, with his horses, slayer of Vrtra, hero with warrior-men; true helper of the worshipper (/truly he helps the worshipper).'

(RV 8.2.35c-36)

In all three examples, there is no necessary future sense, but the reference in all examples is to a characteristic action of the subject which is implied to continue into the future. The context of the Rgvedic hymns, invoking the gods for support, gives an inherently present-future orientation. Thus the sense of these forms does not seem far distant from the use of the periphrastic future at later periods, particularly given that not all examples of the periphrastic future at later periods show a clear future sense (cf. ex. 13). But syntactically, these forms correspond precisely to the syntax of the later periphrastic future, while they do not correspond to a regular construction involving -tŕ- plus copula. At this early period, we are certainly not dealing with a true periphrasis in the sense defined above, but we could perhaps be dealing with a specialized syntactic collocation of agent noun plus (null) copula, for which accusative case objects were licensed, which could be the direct forerunner of the constructions labelled periphrastic future at later periods.

\section{Conclusion}

The traditional analysis of the periphrastic future, as recently updated by Stump (2012), treats it as a paradigmatic tense formation from the early Vedic Prose period onwards. Bonami \& Samvelian (2015)

\footnotetext{
${ }^{41}$ Transitive instances: nicetŕ- x1 (RV 7.57.2a), pranetŕ- x2 (RV 5.61.15b, RV 7.57.2b), upaśrotí- x1 (RV 7.23.1d), possibly apavaktṛ́- x1 (RV 1.24.8d), prayantṛ́- x2 (RV 7.19.1d, RV 4.21.9b), prahantṛ́- x1 (RV 10.27.1c), apavartị́- x1 (RV 4.20.8b), abhisvartí- x1 (RV 10.78.4d).
} 
propose a five-point scale between syntactic construction and synthetic formation in the context of their analysis of periphrasis in Persian:

(38) analytic combination (ordinary head-complement structures) $>$ quasi-analytic (head complement structure with some distributional idiosyncrasies) $>$ true periphrasis (limited syntactic flexibility, paradigmatic integration) > quasi-synthetic (no syntactic flexibility, two lexemes involved) $>$ synthetic combination (ordinary synthetic morphology).

At no period in the history of Sanskrit do we find evidence for a true periphrasis. In early Vedic Prose the construction is clearly paradigmatic, but there is no clear evidence that the construction involves two lexemes, i.e. that it is anything other than a synthetic combination, even in the $1 / 2 \mathrm{sg}$. Pannini's grammar explicitly treats the construction as fully synthetic, and the same therefore applies to later Classical texts which follow Pāninian prescriptions. On the other hand, in Epic Sanskrit, the Purānas, and later texts imitative of the epics, there is no positive evidence for paradigmatic integration, and it appears we are dealing with either a purely analytic, or perhaps quasi-analytic, construction. The usual, but not consistent, lack of distinct feminine/neuter forms of the agent noun with non-masculine subjects is the strongest evidence for quasi-analytic status in this form of Sanskrit, but it does not provide evidence for any degree of paradigmatic integration. Finally, in the Rgveda we may see the beginnings of a quasi-analytic combination in the unexpected transitivity of three instances of the -tŕagent noun.

These findings have a number of significant consequences. They add further evidence in support of the idea that Vedic Prose represents a dialect/sociolect which did not directly feed into the development of post-Vedic Sanskrit (Jamison 1990). The innovation of a periphrastic future paradigm sets early Vedic Prose apart from both Rgvedic and post-Vedic Sanskrit. These findings are also of interest from the perspective of the Sanskrit grammatical tradition and the dating of Pānini. The common assumption is that Pānini's grammar reflects a late Vedic or early post-Vedic dialect. ${ }^{42}$ The fact that Pânini's treatment of the periphrastic future corresponds closely and only to the situation attested in early Vedic Prose, however, supports the arguments of Bronkhorst (1982) that Pạnini's grammar is based on a dialect closer to that of the early Vedic Prose period. This correspondingly suggests an earlier date for Pạnini than is usually assumed. Most importantly, the findings of this paper demonstrate the dangers of ignoring potential variation between different diachronic states of a language. Taking the evidence of early Vedic Prose and later (particularly Epic) Sanskrit as a homogenous whole does lead to the conclusion that the periphrastic future is a true, paradigmatic, periphrasis. But it is clear that such a uniform approach cannot account for the diachronic data, which attests to a construction with different degrees of paradigmatic integration in different periods of Sanskrit.

\section{References}

Ackerman, Farrell \& Stump, Gregory 2004. 'Paradigms and Periphrastic Expression: A Study in Realization-based Lexicalism', in Louisa Sadler \& Andrew Spencer (eds.), Projecting Morphology, Stanford, CA: Center for the Study of Language and Information, 111-158.

Ackerman, Farrell, Stump, Gregory T., \& Webelhuth, Gert 2011. 'Lexicalism, periphrasis, and implicative morphology', in Robert D. Borsley \& Kersti Börjars (eds.), NonTransformational Syntax: Formal and Explicit Models of Grammar, Oxford: Blackwell, 325-358.

\footnotetext{
${ }^{42}$ On Pānini’s language see e.g. Kulikov (2013).
} 
Benveniste, Émile 1948. Noms d'agent et noms d'action en indo-européen, Paris: AdrienMaisonneuve.

Bhatt, G. H., Vaidya, P. L., Divanji, P. C., Mankad, D. R., Jhala, G. C., \& Shah, U. P. 1960-1975. The Vālmīki-Rāmāyana: Critically edited for the first time (7 vols.), Baroda: Oriental Institute. Vol. I, Bālakānda, ed. by G. H. Bhatt, 1960; vol. II, Ayodhyākānda, ed. by P. L. Vaidya, 1962; vol. III, Aranyakāṇda, ed. by P. C. Divanji, 1963; vol. IV, Kiṣkindhākānda, ed. by D. R. Mankad, 1965; vol. V, Sundarakānda, ed. by G. C. Jhala, 1966; vol. VI, Yuddhakānda, ed. by P. L. Vaidya, 1971; vol. VII, Uttarakānda, ed. by U. P. Shah, 1972-1975.

BONAMI, OLIVIER 2015. 'Periphrasis as collocation', Morphology 25, 63-110.

Bonami, Olivier \& Samvelian, Pollet 2009. 'Inflectional periphrasis in Persian', in Stefan Müller (ed.), Proceedings of the 16th International Conference on Head-Driven Phrase Structure Grammar, Stanford, CA: CSLI Publications, 26-46.

Bonami, Olivier \& Samvelian, Pollet 2015. 'The diversity of inflectional periphrasis in Persian', Journal of Linguistics 51(2), 327-382.

Bonami, Olivier \& Webelhuth, Gert 2012. 'The phrase-structural diversity of periphrasis: a lexicalist account', in Marina Chumakina \& Greville Corbett (eds.), Periphrasis: The role of syntax and morphology in paradigms, Oxford: Oxford University Press/The British Academy, 141-167.

BORI, (The Bhandarkar ORIental Research Institute) 1999. 'The Mahābhārata', Authorised and regularly updated electronic text, based on John Smith's revision of Prof. Muneo Tokunaga's version of the text, subjected to detailed checking by a team of assistants based in the Bhandarkar Oriental Research Institute in Pune, made available with BORI's agreement. http://bombay.indology.info/mahabharata/statement.html.

BÖRJARs, Kersti \& Donohue, Mark 2000. 'Much ado about nothing: features and zeroes in Germanic noun phrases', Studia Linguistica 54, 309-353.

Börjars, Kersti, Vincent, Nigel, \& Chapman, Carol 1997. 'Paradigms, periphrases and pronominal inflection: a feature-based account', in Geert Booij \& Jaap van Marle (eds.), Yearbook of Morphology 1996, Dordrecht: Kluwer, 155-180.

Brockington, John L. 1967. The Syntax and Style of the Rāmāyana, Ph.D. thesis, University of Oxford.

Brockington, John L. 1969. 'The Verbal System of the Rāmāyana', Journal of the Oriental Institute, Baroda 19, 1-34. Reprinted in Greg Bailey and Mary Brockington (eds.), 2000, Epic Threads: John Brockington on the Sanskrit Epics, Oxford: Oxford University Press, pp. 13-40.

Brockington, John L. 1998. The Sanskrit Epics, Leiden: Brill.

BronkHorst, Johannes 1982. 'The variationist Pānini and Vedic: A review article', Indo-Iranian Journal 24, 273-282.

Brown, Dunstan, Chumakina, Marina, Corbett, Greville, Popova, Gergana, \& SPENCER, ANDREW 2012. 'Defining 'periphrasis': key notions', Morphology 22(2), 233-275. 
CAMPANILE, EnRICo 1969. 'Sul futuro perifrastico dell' antico indiano', in Studi Linguistici in onore di Vittore Pisani, Brescia: Paideia, 187-204.

Cardona, George 2003. 'Sanskrit', in George Cardona \& Dhanesh Jain (eds.), The Indo-Aryan Languages, London: Routledge, 104-160.

DAHL, EysteIN 2010. Time, Tense and Aspect in Early Vedic Grammar, Leiden: Brill.

DelBRÜCK, BeRTHOLD 1878. Die altindische Wortfolge aus dem Çatapathabrāhmaṇa, Halle: Verlag der Buchhandlung des Waisenhauses.

DelbrüCK, Berthold 1888. Altindische Syntax, Halle: Verlag der Buchhandlung des Waisenhauses.

Fallon, (Translator), Oliver 2009. Bhațti's Poem: the Death of Rāvana, by Bhațti, New York: New York University Press / JJC Foundation. Clay Sanskrit Library edition.

FASSI FEHRI, ABDELKADER 1993. Issues in the structure of Arabic clauses and words, Dordrecht: Kluwer Academic.

GaAstra, Dieuke 1919. Das Gopatha Brāhmana, Leiden: Brill.

Gaedicke, Carl 1880. Der Accusativ im Veda, Breslau: Wilhelm Koebner.

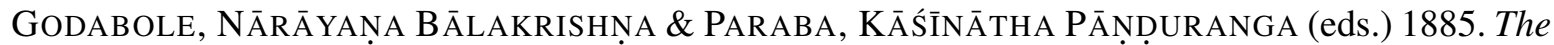
Kirâtârjunîya of Bhâravi, with the commentary (the Ghantâpatha) of Mallinâtha, edited with various readings, Bombay: The Nirnaya-Sâgara Press.

Gonda, Jan 1957. 'A Critical Survey of the Publications on the Periphrastic Future in Sanskrit', Lingua 6, 158-179.

GONDA, JAN 1975. Vedic Literature, Harrassowitz: Wiesbaden. (= History of Indian Literature, Vol. 1, Fasc. 1).

GRIFFITHS, ARLO 2005-2006. 'Gopathabrahmana', Electronic text based on the edition by Gaastra (1919). http://gretil.sub.uni-goettingen.de/gretil/1_sanskr/1_veda/2_bra/gopbra_u.htm.

HARA, MinORU 1987. 'A Note on the Ancient Indian oath (2): use of the periphrastic future', Indologica Taurinensia 14, 201-214.

Haspelmath, Martin 2000. 'Periphrasis', in Geert Booij \& Christian Lehmann (eds.), Morphology: An International Handbook on Inflection and Word-formation, Berlin: Mouton de Gruyter, 654-664.

ISAACSON, HARUNAGA n.d. 'Bharavi: Kiratarjuniya', Electronic text input by Harunaga Isaacson. http://gretil.sub.uni-goettingen.de/gret_utf.htm\#BhaKir.

Jamison, Stephanie W. 1990. 'The Tense of the Predicated Past Participle in Vedic and Beyond', Indo-Iranian Journal 33, 1-19.

Jamison, Stephanie W. 2009. 'Where Are All the Optatives? Modal Patterns in Vedic', in Kazuhiko Yoshida \& Brent Vine (eds.), East and West: Papers in Indo-European Studies, Bremen: Hempen, 27-45. 
Jamison, Stephanie W. forthcoming a. 'The Vedic Perfect Subjunctive and the Value of Modal Forms to Tense/Aspect Stems', To appear in a Festschrift.

Jamison, Stephanie W. forthcoming b. 'The Vedic Perfect Imperative and the Status of Modal Forms to Tense-Aspect Stems', MS, University of California Los Angeles.

Jamison, Stephanie W. \& Brereton, Joel P. 2014. The Rigveda: The Earliest Religious Poetry of India. An English Translation, Oxford/New York: Oxford University Press.

Kiparsky, Paul 2002. 'Event Structure and the Perfect', in David I. Beaver, Luis D. Casillas Martínez, Brady Z. Clark, \& Stefan Kaufmann (eds.), The Construction of Meaning, Stanford, CA: CSLI Publications, 113-136.

KIPARSKY, PAUL 2005. 'Blocking and periphrasis in inflectional paradigms', in Geert Booij \& Jaap van Marle (eds.), Yearbook of Morphology 2004, Dordrecht: Springer, 113-135.

KiPARSKy, PAUl 2016. 'The agent suffixes as a window into Vedic grammar', in Dieter Gunkel, Joshua T. Katz, Brent Vine, \& Michael Weiss (eds.), Sahasram ati srajas: Indo-Iranian and IndoEuropean studies in honour of Stephanie W. Jamison, Ann Arbor: Beech Stave Press, 170-192.

KUliKov, LeONID 2013. 'Language vs. grammatical tradition in Ancient India: How real was Pāninian Sanskrit? Evidence from the history of late Sanskrit passives and pseudo-passives', Folia Linguistica Historica 34, 59-91.

KÜMmel, MARTIN JOACHIM 2015. 'Sankhayana-Aranyaka', Based on the ed. by Bhim Dev, Hoshiarpur 1980 (Vishveshvaranand Indological Series, 70), and the ed. of Adhyayas $7-$ 15 published as an appendix to A.B. Keith: Aitareya Aranyaka, Oxford 1909, pp. 305328. Input by Martin Joachim Kümmel, Jena, last updated 13/01/2015. http://gretil.sub.unigoettingen.de/gretil/1_sanskr/1_veda/3_ara/sankharu.htm.

Lowe, John J. 2013a. 'Indo-European "Transitive" Nouns and the Accusative of Experiencer', in Stephanie W. Jamison, H. Craig Melchert, \& Brent Vine (eds.), Proceedings of the 24th Annual UCLA Indo-European Conference, Bremen: Hempen, 122-136.

Lowe, John J. 2013b. '(De)selecting Arguments for Transitive and Predicated Nominals', in Miriam Butt \& Tracy Holloway King (eds.), Proceedings of the LFG13 Conference, Stanford, CA: CSLI Publications, 398-418.

Lowe, John J. 2014. 'Transitive Nominals in Old Avestan', Journal of the American Oriental Society 134(4), 553-577.

Lowe, John J. 2015. Participles in Rigvedic Sanskrit: The Syntax and Semantics of Adjectival Verb Forms, Oxford: Oxford University Press.

Lowe, John J. 2016. 'Transitive nouns and adjectives in Rgvedic Sanskrit', in Hans Henrich Hock (ed.), Veda and Vedic Literature: Select Papers from the Panel on "Veda and Vedic Literature" at the $16^{\text {th }}$ World Sanskrit Conference (28 June - 2 July 2015), Bangkok, Thailand, New Delhi: DK Publishers Distributors, 25-52.

Lowe, John J. 2017. Transitive Nouns and Adjectives: Evidence from Early Indo-Aryan, Oxford: Oxford University Press. 
Lubotsky, AleXANDER 2002. Atharvaveda-paippalāda, kānda five: text, translation, commentary, Cambridge, MA: Department of Sanskrit and Indian studies, Harvard University.

Narten, Johanna 1968. 'Das altindische Verb in der Sprachwissenschaft', Die Sprache 14, 113134.

Oberlies, Thomas 2003a. 'Aśokan Prakrit and Pāli', in George Cardona \& Dhanesh Jain (eds.), The Indo-Aryan Languages, London: Routledge, 161-203.

Oberlies, Thomas 2003b. A Grammar of Epic Sanskrit, Berlin: de Gruyter.

Pollard, Carl \& Sag, IVAn A. 1994. Head-Driven Phrase Structure Grammar, Chicago: University of Chicago Press.

Popova, Gergana \& SPencer, Andrew 2012. 'Relatedness in periphrasis: a paradigm-based perspective', in Marina Chumakina \& Greville Corbett (eds.), Periphrasis: The role of syntax and morphology in paradigms, Oxford: Oxford University Press/The British Academy, 191-225.

RENOU, Louis 1938. 'Le suffixe védique -tr- et les origines du futur périphrastique', Bulletin de la Société de Linguistique de Paris 39, 103-132.

Renou, Louis 1961. Grammaire sanscrite, Paris: Adrien-Maisonneuve. Second edition: revised, corrected and augmented.

SADLER, LOUISA \& SPENCER, ANDREW 2002. 'Syntax as an exponent of morphological features', in Geert Booij \& Jaap van Marle (eds.), Yearbook of Morphology 2001, Amsterdam: Kluwer, 71-96.

Sag, Ivan A., Wasow, Thomas, \& Bender, Emily 2003. Syntactic Theory: A Formal Introduction, Chicago: University of Chicago Press, second edition.

SHANKAR P. PANDIT (ed.) 1879. The Vikramorvaśîyam, a drama in five acts by Kâlidâsa, edited with English notes, Bombay: Government Central Book Depôt.

Smith, John D. 2014. 'The Rāmāyana', Revision of Prof. Muneo Tokunaga's electronic version of the text. http://bombay.indology. info/ramayana/welcome.html.

SPENCER, ANDREw 2003. 'Periphrastic paradigms in Bulgarian', in Uwe Junghanns \& Luka Szucsich (eds.), Syntactic Structures and Morphological Information, Berlin: Mouton de Gruyter, 249-282.

Spencer, ANDREW 2006. 'Periphrasis', in Keith Brown (ed.), The Encyclopedia of Language and Linguistics, Oxford: Elsevier, 287-293.

SPENCER, ANDREW 2008. 'Negation in Japanese: a case of morphosyntactic mismatch', Lingua 118, 997-1017.

SPENCER, ANDREW 2012. 'Sentence negation and periphrasis', in Marina Chumakina \& Greville G. Corbett (eds.), Periphrasis: the Role of Syntax and Morphology in Paradigms, Oxford: The British Academy and Oxford University Press, 227-266.

Spencer, Andrew \& Popova, Gergana 2015. 'Periphrasis and Inflection', in Matthew Baerman (ed.), The Oxford Handbook of Inflection, Oxford: Oxford University Press, 197-230.

SPEYER, JACOB SAMUEL 1886. Sanskrit Syntax, Leiden: Brill. 
Speyer, JaCob Samuel 1896. Vedische und Sanskrit-Syntax, Strassburg: K. J. Trübner.

Stump, Gregory T. 2001. Inflectional Morphology: A Theory of Paradigm Structure, Cambridge: Cambridge University Press.

STUMP, GREgory T. 2002. 'Morphological and syntactic paradigms: arguments for a theory of paradigm linkage', in Geert Booij \& Jaap van Marle (eds.), Yearbook of Morphology 2001, Amsterdam: Kluwer, 147-180.

Stump, Gregory T. 2012. 'Periphrasis in the Sanskrit verbal system', in Marina Chumakina \& Greville Corbett (eds.), Periphrasis: The role of syntax and morphology in paradigms, Oxford: Oxford University Press/The British Academy, 105-138.

Stump, GRegory T. \& HipPisley, Andrew 2011. 'Valence sensitivity in Pamirian past-tense inflection: a realizational analysis', in Agnes Korn, Geoffrey Haig, Simin Karimi, \& Pollet Samvelian (eds.), Topics in Iranian linguistics, Wiesbaden: Reichert, 103-116.

Sukthankar, V. S., Belvalkar, Shripad Krishna, \& Vaidya, P. L. (eds.) 1933-1966. The Mahābhārata, for the first time critically edited (19 vols.), Poona: Bhandarkar Oriental Research Institute.

TICHY, Eva 1992. 'Wozu braucht das Altindische ein periphrastisches Futur?', Zeitschrift der Deutschen Morgenländischen Gesellschaft 142(2), 334-342.

Tichy, Eva 1995. Die Nomina agentis auf -tar- im Vedischen, Heidelberg: Winter.

TICHY, Eva 2006. Der Konjunktiv und seine Nachbarkategorien: Studien zum indogermanischen Verbum, ausgehend von der älteren vedischen Prosa, Bremen: Hempen.

Ultan, Russell 1978. 'The Nature of Future Tenses', in Joseph H. Greenberg, Charles A. Ferguson, \& Edith A. Moravcsik (eds.), Universals of Human Language: Vol. 3, Word Structure, Stanford, CA: Stanford University Press, 83-123. Reprinted from Working Papers on Language Universals 8 (1972), pp. 55-100.

Watkins, CAlvert 1995. How to Kill a Dragon: Aspects of Indo-European Poetics, Oxford: Oxford University Press.

Whitney, William Dwight 1896. A Sanskrit Grammar: Including both the Classical Language, and the Older Dialects, of Veda and Brahmana, Leipzig: Breitkopf \& Härtel, third edition. 